\title{
Synthesis, Characterization, Antimicrobial, DNA Cleavage, and In Vitro Cytotoxic Studies of Some Metal Complexes of Schiff Base Ligand Derived from Thiazole and Quinoline Moiety
}

\author{
Nagesh Gunvanthrao Yernale and Mruthyunjayaswamy Bennikallu Hire Mathada \\ Department of Studies and Research in Chemistry, Gulbarga University, GULBARGA, Karnataka 585 106, India \\ Correspondence should be addressed to Mruthyunjayaswamy Bennikallu Hire Mathada; bhmmswamy53@rediffmail.com
}

Received 19 October 2013; Accepted 10 January 2014; Published 5 March 2014

Academic Editor: Claudio Pettinari

Copyright ( 2014 N. G. Yernale and M. Bennikallu Hire Mathada. This is an open access article distributed under the Creative Commons Attribution License, which permits unrestricted use, distribution, and reproduction in any medium, provided the original work is properly cited.

\begin{abstract}
A novel Schiff base ligand $N$-(4-phenylthiazol-2yl)-2-((2-thiaxo-1,2-dihydroquinolin-3-yl)methylene)hydrazinecarboxamide (L) obtained by the condensation of $N$-(4-phenylthiazol-2-yl)hydrazinecarboxamide with 2-thioxo-1,2-dihydroquinoline-3carbaldehyde and its newly synthesized $\mathrm{Cu}(\mathrm{II}), \mathrm{Co}(\mathrm{II}), \mathrm{Ni}(\mathrm{II})$, and $\mathrm{Zn}$ (II) complexes have been characterized by elemental analysis and various spectral studies like FT-IR, ${ }^{1} \mathrm{H}$ NMR, ESI mass, UV-Visible, ESR, TGA/DTA, and powder X-ray diffraction studies. The Schiff base ligand $(\mathrm{L})$ behaves as tridentate ONS donor and forms the complexes of type $\left[\mathrm{ML}(\mathrm{Cl})_{2}\right]$ with square pyramidal geometry. The Schiff base ligand (L) and its metal complexes have been screened in vitro for their antibacterial and antifungal activities by minimum inhibitory concentration (MIC) method. The DNA cleavage activity of ligand and its metal complexes were studied using plasmid DNA pBR322 as a target molecule by gel electrophoresis method. The brine shrimp bioassay was also carried out to study the in vitro cytotoxicity properties for the ligand and its metal complexes against Artemia salina. The results showed that the biological activities of the ligand were found to be increased on complexation.
\end{abstract}

\section{Introduction}

Schiff bases are important classes of ligands that coordinate with metal ions via azomethine nitrogen and have been studied extensively because of increasing recognition of their role in biological system [1]. The Schiff bases containing ONS donor atoms act as superior chelating agents for the transition and nontransition metal ions and showed remarkable biological activities [2,3]. Coordination of these compounds with metal ions, such as copper and nickel, often enhance their activities [4]. Bonding between azomethine nitrogen and metal ion was found to be important for biological activity. Several azomethines were reported to possess important antibacterial [5], antifungal [6], anticancer [7], and diuretic activities [8].

Thiazoles are one of the most important classes of heterocycles that have attracted a great deal of interest owing to their wide range of biological properties such as antiprotozoal [9], antimicrobial [10], anti-inflammatory [11], CNS depressant [12], antitubercular [13], antitumor [14, 15], anthelmintic
$[16,17]$, antidiabetics [18], and herbicidal $[19,20]$ activities. Thus, thiazole nucleus has been much studied in the field of medicinal chemistry. Quinolines are a class of nitrogen heterocycles, present in large number of natural and synthetic compounds which exhibit strong biological activities such as antibacterial [21], antifungal [22], antiamoebic [23], antileishmanial [24], antimalarial [25], antitumor [26], immunosuppressive [27], analgesic, vasorelaxing [28], antiplasmodial [29], anticonvulsant, and antihypertensive [30] activities.

A lot of work has been done on the synthesis of compounds using substituted thiazole and quinoline moieties [31, 32]. Literature survey reveals that not much work has been carried out on Schiff base ligand derived from 2-thioxo-1, 2dihydroquinoline-3-carbaldehyde. In view of the above findings and in continuation of our research work on synthesis and characterization of new Schiff base ligands and their metal complexes, we hereby report the synthesis of a novel Schiff base ligand $N$-(4-phenylthiazol-2yl)-2-((2thiaxo-1,2-dihydroquinolin-3-yl)methylene) hydrazine carboxamide (L) and its $\mathrm{Cu}(\mathrm{II}), \mathrm{Co}(\mathrm{II}), \mathrm{Ni}(\mathrm{II})$, and $\mathrm{Zn}(\mathrm{II})$ 
complexes, their characterization by various spectroscopic techniques, and their antimicrobial, DNA cleavage, and in vitro cytotoxicity property.

\section{Materials and Methods}

2.1. Reagents and Instruments. Elemental analysis (C, H, and $\mathrm{N}$ ) was performed on a Vario EL III CHNS analyzer. IR spectra were recorded on a Perkin Elmer-Spectrum RX-I FTIR spectrophotometer using $\mathrm{KBr}$ disc technique in the 4000 to $250 \mathrm{~cm}^{-1}$ region. ${ }^{1} \mathrm{H}$ NMR spectra were recorded on Bruker Avance II $400 \mathrm{MHz}$ NMR Spectrometer in $d_{6}$-DMSO using TMS as an internal standard. ESI mass spectra were recorded by electrospray ionization (ESI) on a Waters Micromass QTof Micro spectrometer. Electronic spectra of the $\mathrm{Cu}(\mathrm{II})$, $\mathrm{Co}(\mathrm{II})$, and $\mathrm{Ni}$ (II) complexes were recorded at $25^{\circ} \mathrm{C}$ on a Elico-SL 164 double beam spectrometer in quartz cells in the range $200-1000 \mathrm{~nm}$ using ca. $10^{-3} \mathrm{M}$ solution in DMF. Molar conductance was measured on the ELICO (CM-185) conductivity bridge using ca. $10^{-3} \mathrm{M}$ solution in dry DMF by dip-type conductivity cell fitted with a platinum electrode. Magnetic susceptibility measurements were measured on a Gouy balance using $\mathrm{Hg}\left[\mathrm{Co}(\mathrm{NCS})_{4}\right]$ as the calibrant at room temperature. ESR measurement of $\mathrm{Cu}$ (II) complex in polycrystalline state was carried out on a JES-FA200 ESR spectrometer with $\mathrm{X}$ and $\mathrm{Q}$ band working at microwave frequency of $8.75-9.65 \mathrm{GHz}$. Thermal analysis of the complexes was carried out on a Perkin Elmer STA 6000 thermal analyzer in static air with a heating rate of $10^{\circ} \mathrm{C} / \mathrm{min}$. Powder X-ray diffraction spectrum of the complexes were recorded on Bruker AXS D8 Advance diffractometer at a wavelength $1.54 \AA$. All chemicals were used as received from commercial sources and solvents are purified according to the literature methods [33]. The melting points of newly synthesized compounds were determined in open glass capillary tubes and are uncorrected. Purity of the compounds was checked by TLC and the spots were observed in iodine vapor. The presence of metal and chloride contents was determined according to standard procedures [33].

Compounds, 2-thioxo-1,2-dihydroquinoline-3-carbaldehyde, and $N$-(4-phenylthiazol-2-yl)hydrazinecarboxamide were prepared according to the reported methods $[31,32]$.

2.2. Synthesis of Schiff Base Ligand $(L)$. An equimolar mixture of $N$-(4-phenylthiazol-2-yl) hydrazinecarboxamide $(0.234 \mathrm{~g}$, $0.001 \mathrm{~mol})$ and 2-thioxo-1,2-dihydroquinoline-3-carbaldehyde $(0.189 \mathrm{~g}, 0.001 \mathrm{~mol})$ in ethanol $(25 \mathrm{~mL})$ was refluxed with a catalytic amount of glacial acetic acid (1-2 drops) for about $7-8 \mathrm{~h}$ on a water bath. The reaction was monitored by TLC. The reaction mixture was cooled to room temperature; pale yellow colored solid separated was filtered, washed with hot ethanol, recrystallized from 1, 4-dioxane, and dried in a desiccator over anhydrous calcium chloride at room temperature (Scheme 1). Yield: $72 \%$; m.p. $298^{\circ}$ C. Anal. Calc. for $\mathrm{C}_{20} \mathrm{H}_{15} \mathrm{~N}_{5} \mathrm{OS}_{2}$ (M.W. = 405): C, 59.25; H, 3.70; N, $17.28 \%$. Found: C, 59.18; H, 3.73; N, 17.21\%. IR data $\left(\nu \mathrm{cm}^{-1}, \mathrm{KBr}\right)$ : $\nu(\mathrm{NH}$ quinoline) 3393; $v(\mathrm{NH}$ amide) 3259; $\nu$ (NH thiazole $)$ $3119 ; \nu(\mathrm{C}=\mathrm{O}) 1688 ; \nu(\mathrm{C}=\mathrm{N}) 1620 ; \nu(\mathrm{C}=\mathrm{S}) 1225 .{ }^{1} \mathrm{H} \operatorname{NMR}\left(d_{6^{-}}\right.$ DMSO; $\delta$ ppm): 13.95 (s, 1H, Quinoline $\mathrm{NH}) ; 10.78$ (s, 1H,

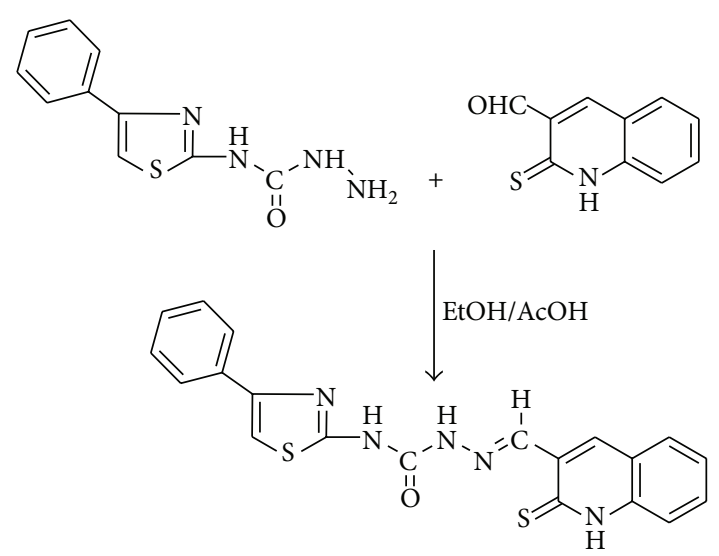

Scheme 1: Synthesis of Schiff base ligand (L).

$\mathrm{CONH}) ; 8.91$ (s, $1 \mathrm{H}, \mathrm{CONH}) ; 8.35$ (s, $1 \mathrm{H}, \mathrm{CH}=\mathrm{N}) ; 7.38-8.25$ (m, 11H, ArH).

2.3. Preparation of $\mathrm{Cu}(\mathrm{II}), \mathrm{Co}(\mathrm{II}), \mathrm{Ni}(\mathrm{II})$ and $\mathrm{Zn}$ (II) Complexes. Hot ethanolic solution $(15 \mathrm{~mL})$ of the respective metal chlorides $(0.001 \mathrm{~mol})$ and the Schiff base ligand $(0.001 \mathrm{~mol})$ in ethanol $(30 \mathrm{~mL})$ were refluxed for about $4-5 \mathrm{~h}$ on a water bath and the $\mathrm{pH}$ of the reaction mixture was adjusted ca. 7.0-7.5 by adding alcoholic solution of sodium acetate $(0.5 \mathrm{~g})$. The reaction mixture was cooled to room temperature and poured in to distilled water. Metal chelates separated were collected by filtration, washed with sufficient quantity of distilled water then with hot ethanol, and finally dried in a desiccator over anhydrous calcium chloride at room temperature.

2.3.1. [ $\left.\mathrm{Cu}\left(\mathrm{C}_{20} \mathrm{H}_{15} \mathrm{~N}_{5} \mathrm{OS}_{2}\right)\left(\mathrm{Cl}_{2}\right)\right]$ : Green Solid. Yield: $73 \%$; m.p. $>320^{\circ} \mathrm{C}$; Anal. Calc. for $\left[\mathrm{Cu}\left(\mathrm{C}_{20} \mathrm{H}_{15} \mathrm{~N}_{5} \mathrm{OS}_{2}\right)\left(\mathrm{Cl}_{2}\right)\right](\mathrm{M} . \mathrm{W} .=$ 539.44): C, 44.49; H, 2.78; N, 12.97; Cl, 13.14; Cu, $11.77 \%$; Found: C, 44.41; H, 2.80; N, 12.93; Cl, 13.17; Cu, 11.79\%. IR data $\left(\nu \mathrm{cm}^{-1}, \mathrm{KBr}\right): \nu(\mathrm{NH}$ quinoline $) 3366 ; \nu(\mathrm{NH}$ amide) 3200 ; $\nu(\mathrm{NH}$ thiazole) $3089 ; \nu(\mathrm{C}=\mathrm{O}) 1656 ; \nu(\mathrm{C}=\mathrm{N}) 1585 ; \nu(\mathrm{C}=\mathrm{S})$ 1188; $v(\mathrm{M}-\mathrm{O}), 514 ; \nu(\mathrm{M}-\mathrm{N}), 454 ; \nu(\mathrm{M}-\mathrm{S}), 372 ; \nu(\mathrm{M}-\mathrm{Cl}), 327$.

2.3.2. $\left[\mathrm{Co}\left(\mathrm{C}_{20} \mathrm{H}_{15} \mathrm{~N}_{5} \mathrm{OS}_{2}\right)\left(\mathrm{Cl}_{2}\right)\right]$ : Brown Solid. Yield: $71 \%$; m.p. $>324^{\circ} \mathrm{C}$; Anal. Calc. for $\left[\mathrm{Co}\left(\mathrm{C}_{20} \mathrm{H}_{15} \mathrm{~N}_{5} \mathrm{OS}_{2}\right)\left(\mathrm{Cl}_{2}\right)\right]$ $($ M.W. $=534.83): \mathrm{C}, 44.87 ; \mathrm{H}, 2.80 ; \mathrm{N}, 13.08 ; \mathrm{Cl}, 13.25 ; \mathrm{Co}$, $11.01 \%$. Found: C, 44.95; H, 2.82; N, 13.15; Cl, 13.21; Co, 11.09\%. IR data $\left(\nu \mathrm{cm}^{-1}, \mathrm{KBr}\right): \nu(\mathrm{NH}$ quinoline) $3295 ; \nu(\mathrm{NH}$ amide $)$ 3192; $v(\mathrm{NH}$ thiazole) $3175 ; \nu(\mathrm{C}=\mathrm{O}) 1633 ; \nu(\mathrm{C}=\mathrm{N}) 1553 ; \nu(\mathrm{C}=\mathrm{S})$ 1215; $v(\mathrm{M}-\mathrm{O}), 536 ; v(\mathrm{M}-\mathrm{N}), 448 ; v(\mathrm{M}-\mathrm{S}), 356 ; v(\mathrm{M}-\mathrm{Cl}), 316$.

2.3.3. $\left[\mathrm{Ni}\left(\mathrm{C}_{20} \mathrm{H}_{15} \mathrm{~N}_{5} \mathrm{OS}_{2}\right)\left(\mathrm{Cl}_{2}\right)\right]$ : Brown Solid. Yield: 69\%; m.p. $>320^{\circ} \mathrm{C}$; Anal. Calc. for $\left[\mathrm{Ni}\left(\mathrm{C}_{20} \mathrm{H}_{15} \mathrm{~N}_{5} \mathrm{OS}_{2}\right)\left(\mathrm{Cl}_{2}\right)\right]$ (M.W. = 534.59): C, 44.89; H, 2.80; N, 13.09; Cl, 13.26; Ni, 10.97\%. Found: C, 44.85; H, 2.75; N, 13.12; Cl, 13.30; Ni, $10.92 \%$. IR data $\left(\nu \mathrm{cm}^{-1}, \mathrm{KBr}\right): \nu(\mathrm{NH}$ quinoline) $3356 ; \nu(\mathrm{NH}$ amide) 3212; $\nu(\mathrm{NH}$ thiazole) $3090 ; \nu(\mathrm{C}=\mathrm{O}) 1656 ; \nu(\mathrm{C}=\mathrm{N})$ 1570; $v(\mathrm{C}=\mathrm{S}) 1216 ; \nu(\mathrm{M}-\mathrm{O}), 522 ; \nu(\mathrm{M}-\mathrm{N}), 476 ; \nu(\mathrm{M}-\mathrm{S}), 337$; $v(\mathrm{M}-\mathrm{Cl}), 320$. 
2.3.4. $\left[\mathrm{Zn}\left(\mathrm{C}_{20} \mathrm{H}_{15} \mathrm{~N}_{5} \mathrm{OS}_{2}\right)\left(\mathrm{Cl}_{2}\right)\right]$ : Orange Yellow Solid. Yield: $70 \%$; m.p. $>310^{\circ} \mathrm{C}$; Anal. Calc. for $\left[\mathrm{Zn}\left(\mathrm{C}_{20} \mathrm{H}_{15} \mathrm{~N}_{5} \mathrm{OS}_{2}\right)\left(\mathrm{Cl}_{2}\right)\right]$ (M.W. = 541.30): C, 44.33; H, 2.77; N, 12.93; Cl, 13.09; Zn, 12.08\%. Found: C, 44.39; H, 2.72; N, 12.92; Cl, 13.15; Zn, $12.03 \%$. IR data $\left(\nu \mathrm{cm}^{-1}, \mathrm{KBr}\right): \nu(\mathrm{NH}$ quinoline $) 3296 ; \nu(\mathrm{NH}$ amide) $3189 ; \nu(\mathrm{NH}$ thiazole) $3103 ; \nu(\mathrm{C}=\mathrm{O}) 1654 ; \nu(\mathrm{C}=\mathrm{N}) 1593$; $v(\mathrm{C}=\mathrm{S}) 1216 ; \nu(\mathrm{M}-\mathrm{O}), 540 ; \nu(\mathrm{M}-\mathrm{N}), 485 ; \nu(\mathrm{M}-\mathrm{S}), 359 ; \nu(\mathrm{M}-$ $\mathrm{Cl}), 312 .{ }^{1} \mathrm{H}$ NMR $\left(d_{6}\right.$-DMSO; $\left.\delta \mathrm{ppm}\right): 11.85$ (s, $1 \mathrm{H}$, Quinoline $\mathrm{NH}) ; 9.25$ (s, $1 \mathrm{H}, \mathrm{CONH}) ; 8.37(\mathrm{~s}, 1 \mathrm{H}, \mathrm{CONH}) ; 8.19$ (s, $1 \mathrm{H}$, $\mathrm{CH}=\mathrm{N}) ; 7.08-8.09(\mathrm{~m}, 11 \mathrm{H}, \mathrm{ArH})$.

\subsection{Biological Evaluation}

2.4.1. In Vitro Antimicrobial Assay. The in vitro antimicrobial activity of the synthesized Schiff base ligand (L) and its $\mathrm{Cu}(\mathrm{II}), \mathrm{Co}(\mathrm{II}), \mathrm{Ni}(\mathrm{II})$, and $\mathrm{Zn}(\mathrm{II})$ complexes were assayed against two gram negative bacterial strains Enterobacter aerogenes (MTCC 111) and Pseudomonas aeruginosa (MTCC 424) and two fungal strains Aspergillus niger (MTCC 282)and Aspergillus flavus (MTCC 277). The above organisms were obtained from the Department of Microbiology and Biotechnology, Gulbarga University, Gulbarga, Karnataka, India, which are previously procured from Institute of Microbial Technology Chandigarh, India. The stock solutions were prepared by dissolving $10 \mathrm{mg}$ of each test compound in $10 \mathrm{~mL}$ of freshly distilled DMSO. The various concentrations of the test compounds $\left(100,50\right.$ and $25 \mu \mathrm{g} \mathrm{mL}^{-1}$ ) were prepared by diluting the stock solution with the required volume of freshly distilled DMSO. The diameter of the zone of inhibition generated by each of the test compounds against bacterial and fungal growth was measured using antibiogram zone measuring scale.

(1) Agar Well Diffusion Assay. In vitro antibacterial and antifungal activities of synthesized Schiff base ligand (L) and its $\mathrm{Cu}(\mathrm{II}), \mathrm{Co}(\mathrm{II}), \mathrm{Ni}(\mathrm{II})$, and $\mathrm{Zn}(\mathrm{II})$ complexes were determined by standard agar well diffusion assay. MuellerHinton agar media were used for antibacterial studies. The pure dehydrated Mueller-Hilton agar $(38 \mathrm{~g})$ dissolved in $1000 \mathrm{~mL}$ of distilled water. The pure cultures of the bacterial strains Enterobacter aerogenes and Pseudomonas aeruginosa were subcultured by inoculating in the nutrient broth and were incubated at $37^{\circ} \mathrm{C}$ for about $18 \mathrm{~h}$. The agar plates were prepared by using the above media and wells were dug with the help of $6 \mathrm{~mm}$ sterile metallic cork borer. Each plate was inoculated with $18 \mathrm{~h}$ old bacterial culture $(100 \mu \mathrm{L})$ using a micropipette and spread uniformly using bent glass rod on each plate. Different concentrations of the test compounds $\left(100,50\right.$, and $\left.25 \mu \mathrm{g} \mathrm{mL}^{-1}\right)$ were incorporated into the wells using micropipette and the plates were kept for incubation at $37^{\circ} \mathrm{C}$ for $24 \mathrm{~h}$. After the completion of incubation period, the diameters of the inhibition zones generated by each test compound against bacterial growth were measured using antibiogram zone measuring scale. The experiment done in triplicate and the average values were calculated for antibacterial activity.

Potato dextrose agar (PDA) media were used for the antifungal studies. The following ingredients were used to prepare the medium. Potatoes (sliced, washed, unpeeled $200 \mathrm{~g})$, dextrose $(20 \mathrm{~g})$, agar $(20 \mathrm{~g})$ in $1000 \mathrm{~mL}$ distilled water.
The pure cultures Aspergillus niger and Aspergillus flavus were inoculated on PDA slants. These slants were incubated at $32^{\circ} \mathrm{C}$ for 7 days. To these 7-day-old slants of fungal strains, $10 \mathrm{~mL}$ of $0.1 \%$ tween- 80 solution was added and the culture was scraped with sterile inoculating loop to get uniform spore suspension. The agar plates were prepared by using the above potato dextrose agar media and wells were dug with the help of $6 \mathrm{~mm}$ sterile metallic cork borer. Each plate was inoculated with 7-day-old spore suspension of each fungal culture $(100 \mu \mathrm{L})$ using a micropipette and spread uniformly using bent glass rod on each plates. Each well was incorporated with the test compound solution of different concentrations (100, 50 , and $25 \mu \mathrm{g} \mathrm{mL}^{-1}$ ). All the inoculated plates were incubated at $32^{\circ} \mathrm{C}$ for about $48 \mathrm{~h}$. After the completion of incubation period, the diameters of the inhibition zones generated by each test compound against fungal growth were measured using antibiogram zone measuring scale. The experiment done in triplicate and the average values were calculated for antifungal activity.

(2) Minimum Inhibitory Concentration (MIC). Minimum inhibitory concentration (MIC) was defined as the lowest concentration where no visible turbidity was observed in the test tubes $[34,35]$. Minimum inhibitory concentration of the compounds was determined in nutrient agar plate by microdilution method according to the National Committee for Clinical Laboratory Standards [36]. Standardized suspension of test organisms $\left(0.1 \mathrm{~mL}, 10^{6} \mathrm{cfu} / \mathrm{mL}\right)$ and synthesized Schiff base ligand (L) and its $\mathrm{Cu}(\mathrm{II}), \mathrm{Co}(\mathrm{II}), \mathrm{Ni}(\mathrm{II})$, and $\mathrm{Zn}(\mathrm{II})$ complexes in different concentrations $(100,50,25,12.50,6.25$, $3.125,1.563,0.78,0.39$, and $0.195 \mu \mathrm{g} / \mathrm{mL}$ ) were taken in test tubes and test tubes with Gentamycin and Fluconazole as positive control for bacterial and fungal strains, respectively. DMSO is used as a negative control for antibacterial and antifungal, respectively. The bacterial tubes were incubated at $37^{\circ} \mathrm{C}$ for $18 \mathrm{~h}$ and fungal tubes were incubated at $32^{\circ} \mathrm{C}$ for $48 \mathrm{~h}$. The lowest concentration that produced no visible bacterial growth compared with the control tubes was regarded as MIC.

2.4.2. DNA Cleavage Activity. In order to study whether newly synthesized Schiff base ligand and its metal complexes could behave as DNA cleaving agents or not, they were examined using plasmid pBR322 DNA (Bangal re Genei, Bengaluru, Cat. No 105850) as a target molecule according to the literature method [37].

The cleavage activity of the test compounds was analyzed by agarose gel electrophoresis method. The $600 \mathrm{mg}$ of agarose was dissolved in $60 \mathrm{~mL}$ of TAE buffer (4.84 g Tris base, $\mathrm{pH}$ 8.0, $0.5 \mathrm{M}$ EDTA) by boiling. When the gel attains approximately $55^{\circ} \mathrm{C}$, it was poured into the gel cassette fitted with comb. The gel was allowed to solidify and then carefully the comb was removed. The gel was placed in the electrophoresis chamber flooded with TAE buffer. Test compounds were prepared in DMSO $\left(1 \mathrm{mg} \mathrm{mL}^{-1}\right)$. The test compounds were added separately to the isolated plasmid pBR322 DNA $(225 \mathrm{ng})$ and incubated for $2 \mathrm{~h}$ at $37^{\circ} \mathrm{C}$. After the incubation period, the $20 \mu \mathrm{L}$ of DNA sample (mixed with bromophenol blue dye at a 1:1 ratio) was loaded carefully into the electrophoresis chamber wells along with standard DNA marker and 
a constant electricity of $50 \mathrm{~V}$ passed for about $30 \mathrm{~min}$. The gel was removed carefully and stained with Ethidium bromide (EtBr) solution $(10 \mu \mathrm{g} / \mathrm{mL})$ for $10-15 \mathrm{~min}$. The bands were observed under UV transilluminator (UVP, Germany) and photographed to determine the extent of DNA cleavage, and the results were compared with those of a standard DNA marker.

2.4.3. In Vitro Cytotoxicity. The brine shrimp lethality bioassay has been chosen to evaluate the in vitro cytotoxic effect of the newly synthesized Schiff base ligand (L) and its $\mathrm{Cu}$ (II), $\mathrm{Co}(\mathrm{II}), \mathrm{Ni}(\mathrm{II})$, and $\mathrm{Zn}$ (II) complexes by using the protocol of Meyer et al. [38]. This is an efficient, rapid, inexpensive test and has a good correlation with cytotoxic activity.

Brine shrimp (Artemia salina) eggs were hatched in a shallow rectangular plastic dish $(22 \times 32 \mathrm{~cm})$ filled with artificial seawater, which was prepared with a commercial salt mixture and double distilled water. An unequal partition was made in the plastic dish with the help of a perforated device. Approximately $50 \mathrm{mg}$ of eggs were sprinkled into the large compartment, which was darkened while the minor compartment was open to ordinary light. After two days nauplii were collected by a pipette from the lighted side. A sample of the test compound was prepared by dissolving $20 \mathrm{mg}$ of each compound in $2 \mathrm{~mL}$ of DMSO. From this stock solution 100, 50 , and $25 \mu \mathrm{g} \mathrm{mL}^{-1}$ were transferred to nine vials (three for each dilution were used for each test sample and $\mathrm{LD}_{50}$ is the mean of three values) and one vial was kept as control having $2 \mathrm{~mL}$ of DMSO only. The solvent was allowed to evaporate overnight. After two days, when shrimp larvae were ready, $1 \mathrm{~mL}$ of seawater and 10 shrimps were added to each vial (30 shrimps/dilution) and the volume was adjusted with seawater to $10 \mathrm{~mL}$ per vial. After $24 \mathrm{~h}$ the number of survivors was counted. Data were analysed by a Finney computer program to determine the $\mathrm{LD}_{50}$ values [39].

\section{Results and Discussion}

The reaction of Schiff base ligand (L) with $\mathrm{Cu}(\mathrm{II}), \mathrm{Co}(\mathrm{II})$, $\mathrm{Ni}(\mathrm{II})$, and $\mathrm{Zn}$ (II) ions in 1:1 ratio resulted in the complex of the type $\left[\mathrm{ML}(\mathrm{Cl})_{2}\right]$. The physical and analytical data agree well with the proposed composition of Schiff base ligand and its $\mathrm{Cu}(\mathrm{II}), \mathrm{Co}(\mathrm{II}), \mathrm{Ni}(\mathrm{II})$, and $\mathrm{Zn}$ (II) complexes. The newly synthesized complexes are colored solids, stable in air, and insoluble in water and common organic solvents but completely soluble in DMF and DMSO. The molar conductance data of the complexes was measured in DMF at ca. $10^{-3} \mathrm{M}$ and all the complexes showed conductance in the range of 50$61 \mathrm{Ohm}^{-1} \mathrm{~cm}^{2} \mathrm{~mol}^{-1}$ at room temperature indicating nonelectrolytic nature of the complexes suggesting that the $\mathrm{Cl}^{-}$ anion is coordinated to metal ion. This was further supported by the proposed general formula of the complexes based upon the results of elemental analysis (Table 1) and spectral data.

3.1. IR Spectra. IR spectrum of the ligand showed a high intensity band at $1688 \mathrm{~cm}^{-1}$ due to $\nu(\mathrm{C}=\mathrm{O})$ and three absorption bands at 3393,3259 , and $3119 \mathrm{~cm}^{-1}$ due to quinoline $\mathrm{NH}$, amide $\mathrm{NH}$, and $\mathrm{NH}$ attached to thiazole moiety, respectively.
A high intensity band observed at $1620 \mathrm{~cm}^{-1}$ is attributed to the azomethine $v(\mathrm{C}=\mathrm{N})$ vibration and a band at $1225 \mathrm{~cm}^{-1}$ to $\nu(\mathrm{C}=\mathrm{S})$ functioning at 2-position of quinoline moiety.

In order to study the binding mode of the Schiff base to the metal ion in complexes, the IR spectrum of the free ligand was compared with the spectra of the complexes. In the IR spectra of the complexes, medium intensity weak bands at 3366-3295, 3212-3189, and 3175-3089 $\mathrm{cm}^{-1}$ were due to quinoline $\mathrm{NH}$, amide $\mathrm{NH}$, and $\mathrm{NH}$ attached to thiazole moiety, respectively, which appeared at about the same region as in the case of ligand indicating their noninvolvement in coordination. The shift of amide carbonyl $\nu(\mathrm{C}=\mathrm{O})$ to lower frequency side about $55-32 \mathrm{~cm}^{-1}$ which appeared in the region $1656-1633 \mathrm{~cm}^{-1}$ in all the complexes confirms the coordination of oxygen atom of amide $\mathrm{C}=\mathrm{O}$ with the metal ions as such without undergoing enolization [40]. The IR spectrum of all the complexes showed a shift of the azomethine $v(\mathrm{C}=\mathrm{N})$ band towards lower frequency side about 67$27 \mathrm{~cm}^{-1}$ and appeared in the region $1593-1553 \mathrm{~cm}^{-1}$ when compared with the free ligand indicating the coordination of the azomethine nitrogen to the metal ions [41]. The shift of band due to $v(\mathrm{C}=\mathrm{S})$ in all the complexes towards lower frequency side by $37-9 \mathrm{~cm}^{-1}$ when compared to the ligand, which appeared in the region $1215-1188 \mathrm{~cm}^{-1}$, proves the coordination of the sulfur atom of quinoline 2-thione to metal ions. The formation of complex was further confirmed by the appearance of new bands in the regions 540-514, $485-448,372-337$, and $327-312 \mathrm{~cm}^{-1}$ in all the complexes due to skeletal metal-oxygen, metal-nitrogen, metal-sulfur, and metal-chloride vibrations, respectively. The important IR spectral data of the Schiff base ligand and its metal complexes are represented in Table 2.

3.2. ${ }^{1} H$ NMR Spectra. The ${ }^{1} \mathrm{H}$ NMR spectrum of ligand displayed four distinct singlets at $\delta 13.95(\mathrm{~s}, 1 \mathrm{H}$, quinoline $\mathrm{NH})$, $\delta 10.78(\mathrm{~s}, 1 \mathrm{H}, \mathrm{CONH}), \delta 8.91(\mathrm{~s}, 1 \mathrm{H}, \mathrm{CONH})$, and $\delta 8.35(\mathrm{~s}$, $1 \mathrm{H}, \mathrm{CH}=\mathrm{N})$ and eleven aromatic protons as multiplets in the region $\delta 7.38-8.25(\mathrm{~m}, 11 \mathrm{H}, \mathrm{ArH})$.

The ${ }^{1} \mathrm{H}$ NMR of $\mathrm{Zn}(\mathrm{II})$ complex displayed four distinct singlets at $\delta 11.85(\mathrm{~s}, 1 \mathrm{H}$, quinoline $\mathrm{NH}), \delta 9.25(\mathrm{~s}, 1 \mathrm{H}$, $\mathrm{CONH}), 8.37$ (s, $1 \mathrm{H}, \mathrm{CONH})$, and $8.19(\mathrm{~s}, 1 \mathrm{H}, \mathrm{CH}=\mathrm{N})$ and eleven aromatic protons as multiplets in the region 7.08-8.09 (m, 11H, ArH). The ${ }^{1} \mathrm{H}$ NMR spectral data of Schiff base ligand and its $\mathrm{Zn}$ (II) complex confirm the formation of $\mathrm{Zn}$ (II) complex with the ligand.

3.3. ESI Mass Spectral Data. The ESI mass spectra of the Schiff base ligand (L) and its $\mathrm{Co}(\mathrm{II})$ and $\mathrm{Ni}(\mathrm{II})$ complexes are performed to determine their molecular weight and study their fragmentation pattern. The mass spectrum of ligand showed a peak recorded at $m / z 406$ (3.93\%) due to $\mathrm{M}^{+\bullet}+1$ (Figure 1). This on loss of hydrogen radical gave a peak at $\mathrm{m} / z$ $405(2.36 \%)$ which is equivalent to its molecular weight (M.W. $=405$ ). Further, this molecular ion underwent fragmentation by two routes. First, on loss of $\mathrm{SH}$ radical, it gave a fragment ion peak recorded at $m / z 372$ (2.36\%), followed by expulsion of $\mathrm{C}_{10} \mathrm{H}_{6} \mathrm{~N}_{2}$ molecule which gave a fragment ion peak 


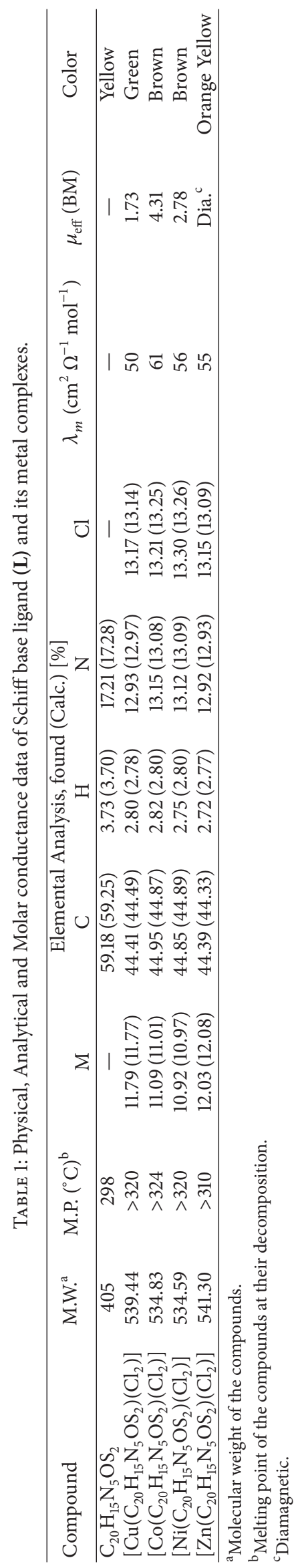


TABLE 2: IR spectral data of Schiff base ligand (L) and its metal complexes.

\begin{tabular}{|c|c|c|c|c|c|c|c|c|c|c|}
\hline Compounds & $\begin{array}{c}\text { Quinoline } \\
v_{(\mathrm{NH})} \\
\mathrm{cm}^{-1}\end{array}$ & $\begin{array}{c}\text { Amide } \\
\nu_{(\mathrm{NH})} \\
\mathrm{cm}^{-1}\end{array}$ & $\begin{array}{c}\text { Thiazole } \\
v_{(\mathrm{NH})} \\
\mathrm{cm}^{-1}\end{array}$ & $\begin{array}{c}v_{(\mathrm{C}=\mathrm{O})} \\
\mathrm{cm}^{-1}\end{array}$ & $\begin{array}{c}\nu_{(\mathrm{C}=\mathrm{N})} \\
\mathrm{cm}^{-1}\end{array}$ & $\begin{array}{c}v_{(\mathrm{C}=\mathrm{S})} \\
\mathrm{cm}^{-1}\end{array}$ & $\begin{array}{c}v_{(\mathrm{M}-\mathrm{O})} \\
\mathrm{cm}^{-1}\end{array}$ & $\begin{array}{c}v_{(\mathrm{M}-\mathrm{N})} \\
\mathrm{cm}^{-1}\end{array}$ & $\begin{array}{l}v_{(\mathrm{M}-\mathrm{S})} \\
\mathrm{cm}^{-1}\end{array}$ & $\begin{array}{c}v_{(\mathrm{M}-\mathrm{Cl})} \\
\mathrm{cm}^{-1}\end{array}$ \\
\hline $\mathrm{C}_{20} \mathrm{H}_{15} \mathrm{~N}_{5} \mathrm{OS}_{2}$ & 3393 & 3259 & 3119 & 1688 & 1620 & 1225 & - & - & - & - \\
\hline$\left[\mathrm{Cu}\left(\mathrm{C}_{20} \mathrm{H}_{15} \mathrm{~N}_{5} \mathrm{OS}_{2}\right)\left(\mathrm{Cl}_{2}\right)\right]$ & 3366 & 3200 & 3089 & 1656 & 1585 & 1188 & 514 & 454 & 372 & 327 \\
\hline$\left[\mathrm{Co}\left(\mathrm{C}_{20} \mathrm{H}_{15} \mathrm{~N}_{5} \mathrm{OS}_{2}\right)\left(\mathrm{Cl}_{2}\right)\right]$ & 3295 & 3192 & 3175 & 1633 & 1553 & 1215 & 536 & 448 & 356 & 316 \\
\hline$\left[\mathrm{Ni}\left(\mathrm{C}_{20} \mathrm{H}_{15} \mathrm{~N}_{5} \mathrm{OS}_{2}\right)\left(\mathrm{Cl}_{2}\right)\right]$ & 3356 & 3212 & 3090 & 1656 & 1570 & 1216 & 522 & 476 & 337 & 320 \\
\hline$\left[\mathrm{Zn}\left(\mathrm{C}_{20} \mathrm{H}_{15} \mathrm{~N}_{5} \mathrm{OS}_{2}\right)\left(\mathrm{Cl}_{2}\right)\right]$ & 3296 & 3189 & 3103 & 1654 & 1593 & 1216 & 540 & 485 & 359 & 312 \\
\hline
\end{tabular}

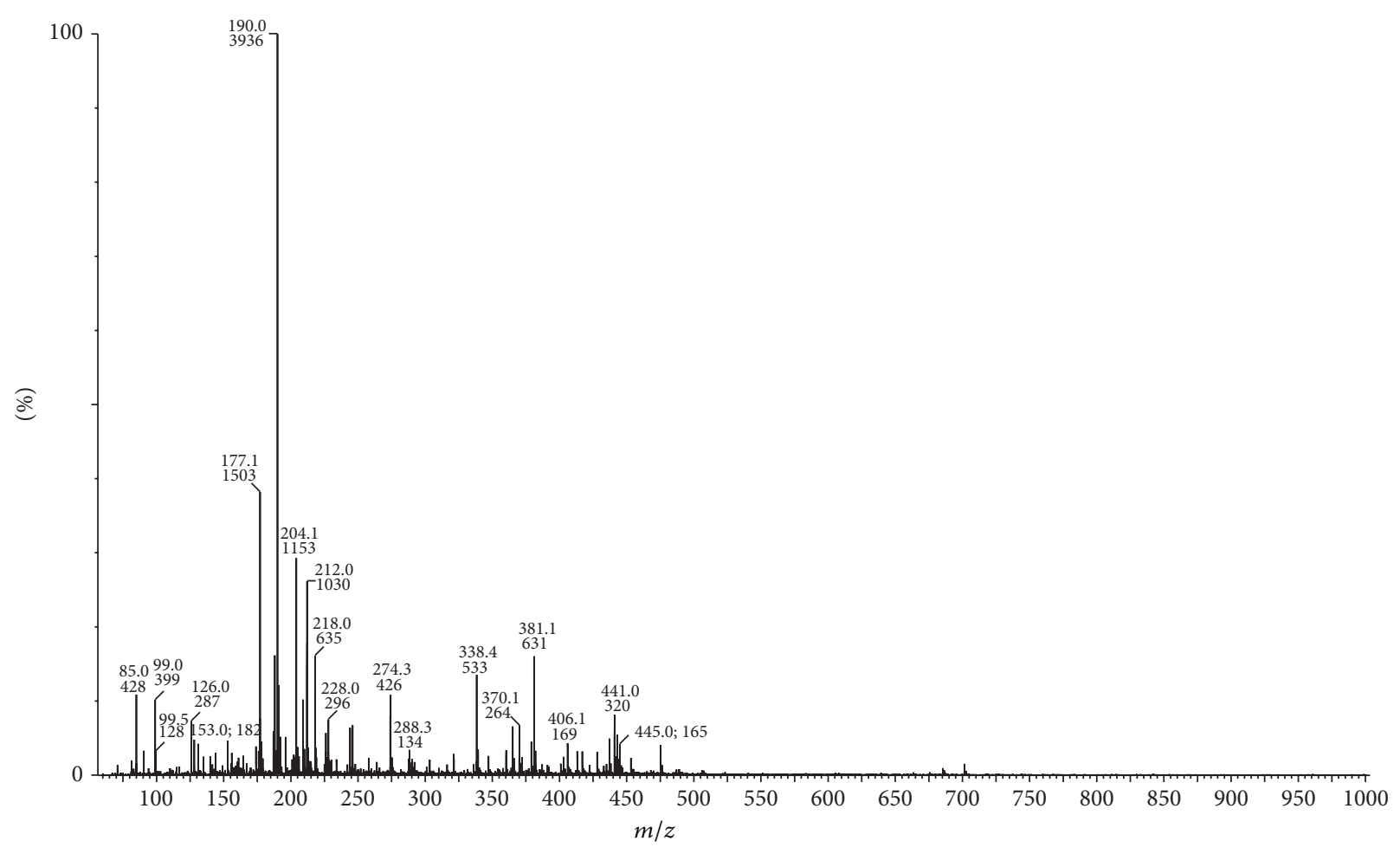

FIGURE 1: ESI mass spectrum of Schiff base ligand (L).

recorded at $m / z 218$ (14.98\%). This fragment ion on further expulsion of CO molecule gave a fragment ion peak at $\mathrm{m} / z$ $190(100 \%)$ which is also a base peak. This base peak on loss of $\mathrm{NH}_{2}$ radical gives a fragment ion peak recorded at $\mathrm{m} / z$ $174(3.93 \%)$. The molecular ion underwent fragmentation in another route wherein it losses $\mathrm{SH}$ radical and $\mathrm{C}_{10} \mathrm{H}_{5} \mathrm{~N}_{2}$ radical simultaneously giving a fragment ion peak recorded at $m / z 219(2.36 \%)$. This fragment ion on further loss of NCO radical gave a fragment ion peak recorded at $m / z 177$ (38.58\%). This schematic mass spectral fragmentation pattern of ligand is in consistency with its structure which is depicted in Scheme 2.

The ESI mass spectrum of $\mathrm{Co}(\mathrm{II})$ complex exhibited a peak due to $\mathrm{M}^{+\bullet}+1$ at $m / z 534(5.51 \%)$. This on loss of hydrogen radical gave a peak at $m / z 533(2.30 \%)$, which is equivalent to its molecular weight $($ M.W. = 533). This molecular ion underwent fragmentation by two routes. First, on simultaneous loss of chlorine molecule, $\mathrm{N}=\mathrm{C}=\mathrm{S}$ radical, $\mathrm{C}_{9} \mathrm{H}_{5}$ radical, and $\mathrm{C}_{8} \mathrm{H}_{5} \mathrm{~N}$ species gave a fragment ion peak recorded at $m / z$
$177(100 \%)$ which is also a base peak. In another route, the molecular ion peak on loss of $\mathrm{N}=\mathrm{C}=\mathrm{S}$ radical gave a fragment ion peak recorded at $m / z 475$ (35.43\%). The schematic mass spectral fragmentation pattern of $\mathrm{Co}$ (II) complex of ligand is in consistency with its structure which is depicted in Scheme 3.

Similarly, the mass spectra of $\mathrm{Ni}(\mathrm{II})$ complex exhibited a peak at $m / z 534(4.72 \%)$ due to $\mathrm{M}^{+\bullet}+1$ (Figure 2 ). This is on loss of hydrogen radical gave the fragment ion peak recorded at $m / z 533(2.23 \%)$, which is equivalent to its molecular weight $($ M.W. $=533)$. Further this molecular ion underwent fragmentation by the loss of hydrogen radical and chlorine molecule simultaneously giving a fragment ion peak recorded at $m / z 462$ (29.92\%). This on further loss of $\mathrm{C}_{7} \mathrm{H}_{5} \mathrm{~N}$ molecule gave a fragment ion peak recorded at $m / z 359$ (3.14\%), which underwent fragmentation by two routes. First, on loss of $\mathrm{H}-$ $\mathrm{C} \equiv \mathrm{C}$ radical and two hydrogen radicals it simultaneously gave a fragment ion peak recorded at $m / z 332$ (21.25\%), which on further expulsion of $\mathrm{C}=\mathrm{S}$ molecule gave a fragment ion peak 


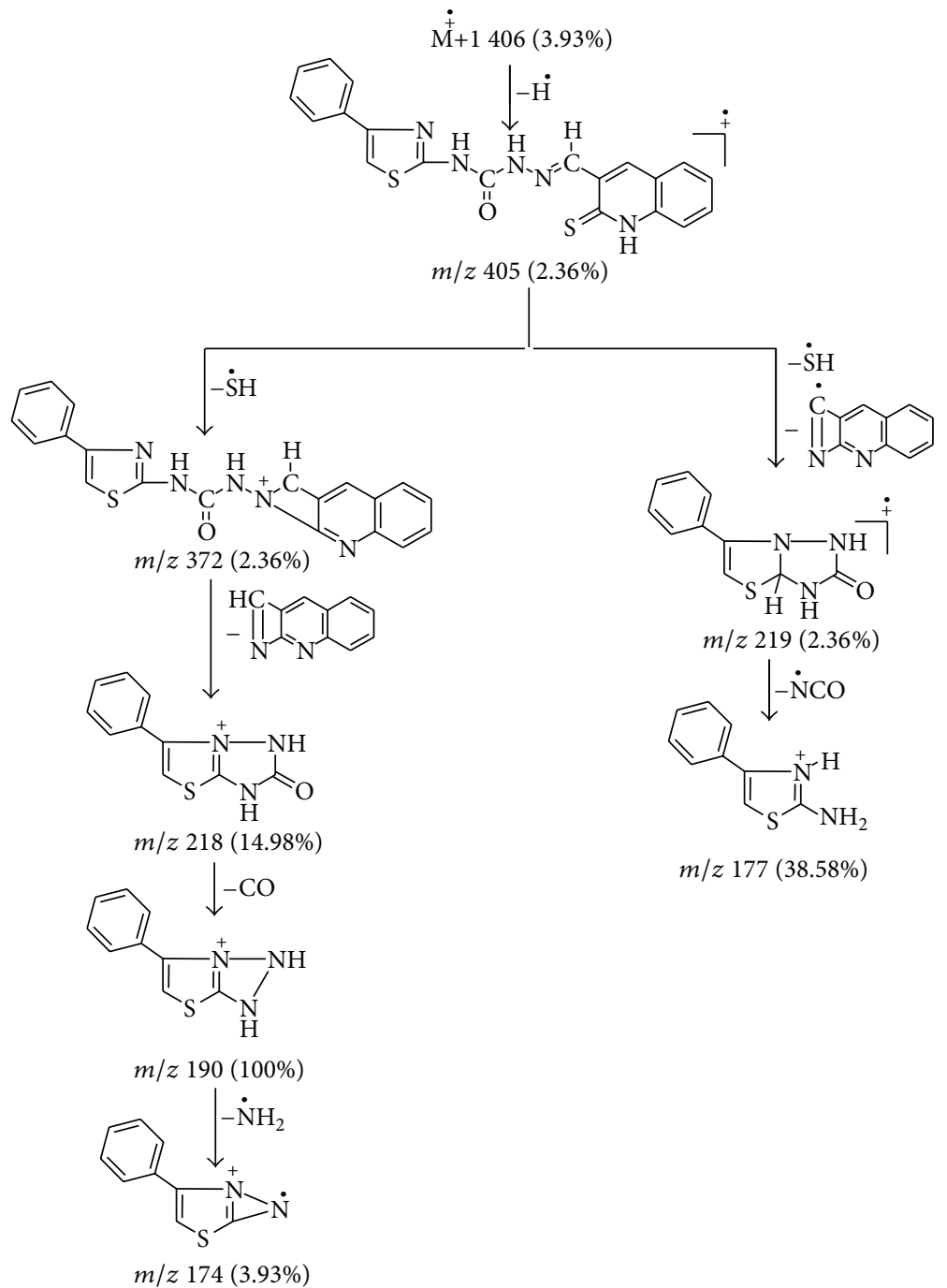

Scheme 2: Mass fragmentation pattern of Schiff base ligand (L).

recorded at $m / z 288(6.29 \%)$. In another route, fragment ion peak recorded at $m / z 359(3.14 \%)$ on simultaneous loss of $\mathrm{C}_{9} \mathrm{H}_{4} \mathrm{NS}$ radical and $\mathrm{C} \equiv \mathrm{C}-\mathrm{H}$ radical gave a fragment ion peak recorded at $m / z 177(100 \%)$ which is also a base peak. The schematic mass spectral fragmentation pattern of $\mathrm{Ni}$ (II) is in consistency with its structure which is depicted in Scheme 4.

3.4. Electronic Spectra and Magnetic Susceptibility. The electronic spectra of the $\mathrm{Cu}(\mathrm{II}), \mathrm{Co}(\mathrm{II})$, and $\mathrm{Ni}(\mathrm{II})$ complexes were recorded in DMF solution at ca. $10^{-3} \mathrm{M}$ at room temperature. The band positions of absorption band maxima assignments are listed in Table 3. The electronic spectra of green colored $\mathrm{Cu}$ (II) complex showed three absorption bands around $9993 \mathrm{~cm}^{-1}, 14595 \mathrm{~cm}^{-1}$, and $18045 \mathrm{~cm}^{-1}$ which are assigned to ${ }^{2} \mathrm{~B}_{1} \rightarrow{ }^{2} \mathrm{~A}_{1}\left(\nu_{1}\right),{ }^{2} \mathrm{~B}_{1} \rightarrow{ }^{2} \mathrm{~B}_{2}\left(\nu_{2}\right)$, and ${ }^{2} \mathrm{~B}_{1} \rightarrow{ }^{2} \mathrm{E}\left(v_{3}\right)$ transitions, respectively. The observed transitions for $\mathrm{Cu}$ (II) complex are well within the ranges of $9000-10000 \mathrm{~cm}^{-1}\left(\nu_{1}\right)$, $11500-16000 \mathrm{~cm}^{-1}\left(\nu_{2}\right)$, and $15000-19000 \mathrm{~cm}^{-1}\left(\nu_{3}\right)$ for $\mathrm{Cu}(\mathrm{II})$ complexes of square pyramidal geometry $[42,43]$. The electronic spectra of brown colored $\mathrm{Co}$ (II) complex displayed three absorption bands at $11098 \mathrm{~cm}^{-1}, 17675 \mathrm{~cm}^{-1}$, and $20180 \mathrm{~cm}^{-1}$ which are assigned to ${ }^{4} \mathrm{~A}_{2}+{ }^{4} \mathrm{E} \rightarrow{ }^{4} \mathrm{~B}_{1}\left(\nu_{1}\right),{ }^{4} \mathrm{~A}_{2}+$ ${ }^{4} \mathrm{E} \rightarrow{ }^{4} \mathrm{E}(\mathrm{P})\left(\nu_{2}\right)$, and ${ }^{4} \mathrm{~A}_{2}+{ }^{4} \mathrm{E} \rightarrow{ }^{4} \mathrm{~A}_{2}(\mathrm{P})\left(\nu_{3}\right)$ transitions, respectively, suggesting the square pyramidal geometry of the Co(II) complex [44]. The brown colored Ni(II) complex under present investigation displayed three absorption band at $10000 \mathrm{~cm}^{-1}, 13543 \mathrm{~cm}^{-1}$, and $22307 \mathrm{~cm}^{-1}$ which are assigned to transitions ${ }^{3} \mathrm{~B}_{1} \rightarrow{ }^{3} \mathrm{E}^{\mathrm{a}}\left(\nu_{1}\right),{ }^{2} \mathrm{~B}_{1} \rightarrow{ }^{3} \mathrm{~A}_{2}\left(\nu_{2}\right)$, and ${ }^{3} \mathrm{~B}_{1} \rightarrow{ }^{3} \mathrm{E}^{\mathrm{b}}\left(\nu_{3}\right)$, respectively, indicating the square pyramidal geometry of the $\mathrm{Ni}(\mathrm{II})$ complex [45].

The magnetic moment value for $\mathrm{Cu}(\mathrm{II})$ complex was found to be $1.73 \mathrm{BM}$ which is in the range of $1.71-1.76 \mathrm{BM}$, agreeing well with the spin value of $S=1 / 2$, as usually observed for $\mathrm{Cu}(\mathrm{II})$ complex, which supports its square pyramidal geometry [46]. The magnetic moment value for $\mathrm{Co}$ (II) complex was found to be $4.31 \mathrm{BM}$ which is in the range 4.3-4.6 BM, for five coordinate square pyramidal geometries of $\mathrm{Co}$ (II) complex [47]. The magnetic moment of $\mathrm{Ni}$ (II) complex was found to be $2.78 \mathrm{BM}$, which is well within the range 


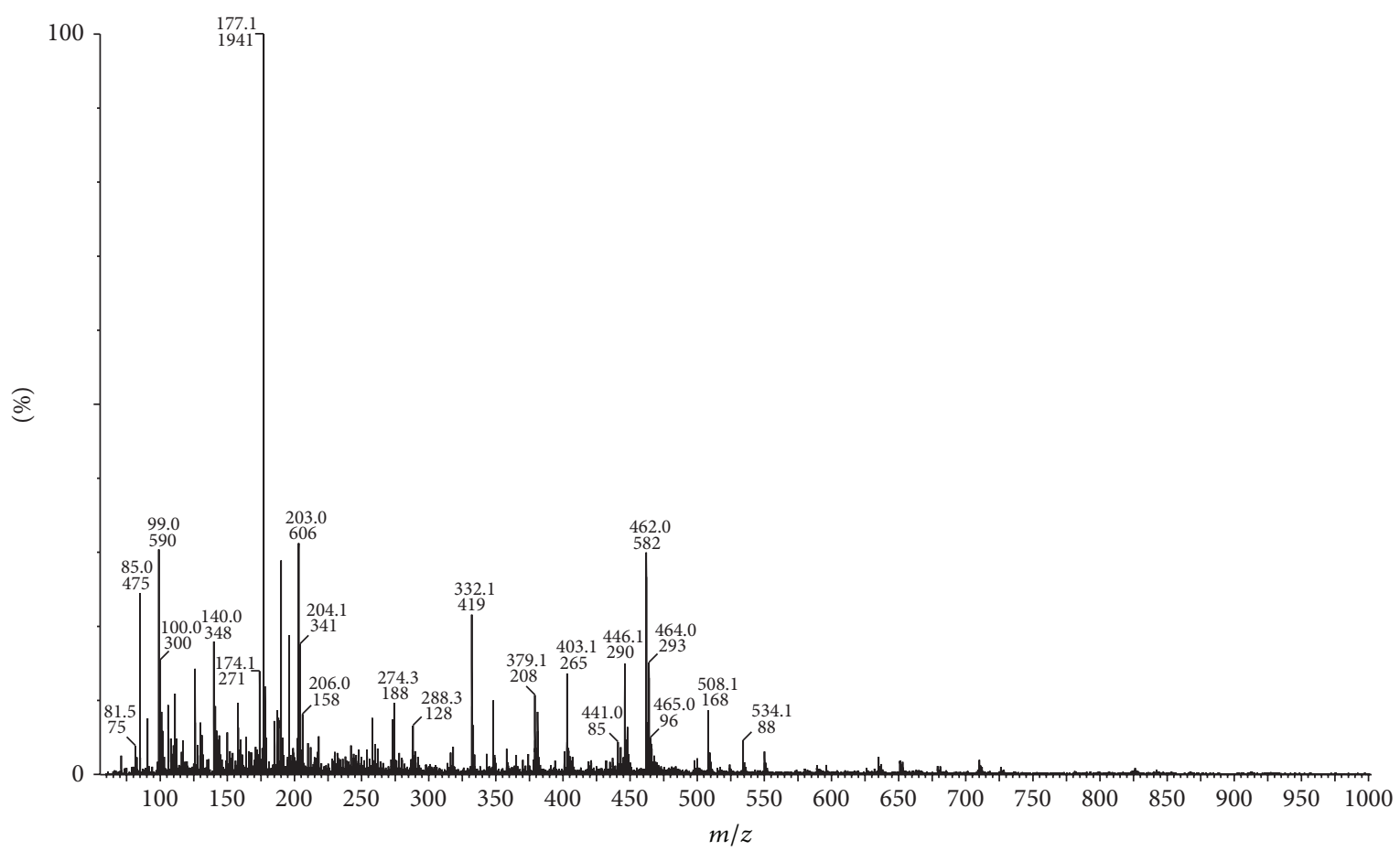

FIGURE 2: ESI mass spectrum of Ni(II) complex.

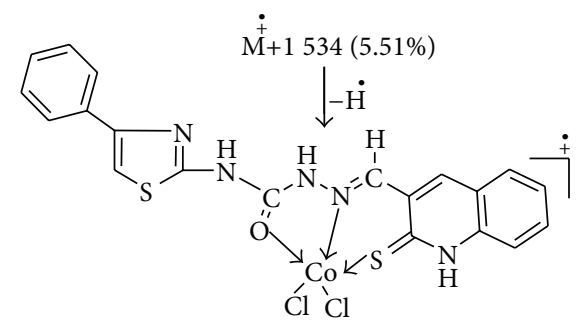

$m / z 533(2.30 \%)$

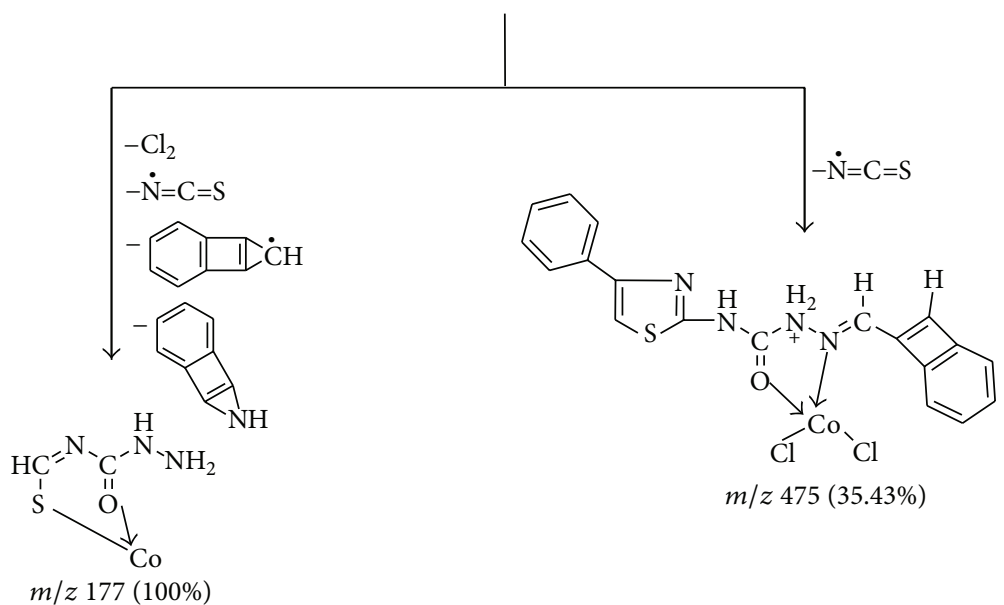

Scheme 3: Mass fragmentation pattern of Co(II) complex.

known for five coordinated square pyramidal geometries of $\mathrm{Ni}(\mathrm{II})$ complex [45].

3.5. ESR Spectra. In order to obtain further information about the stereochemistry and site of the metal-ligand bonding and determine the magnetic interaction in the metal complexes, the X-band ESR spectrum of $\mathrm{Cu}$ (II) complex has been recorded in the polycrystalline state at room temperature using DPPH as a standard. The ESR spectrum of $\mathrm{Cu}(\mathrm{II})$ complex exhibited a single broad signal (Figure 3 ) due to dipolar broadening and enhanced spin lattice relaxation. The ESR spectra of $\mathrm{Cu}$ (II) complex exhibited auxiliary symmetric 
TABLE 3: Electronic and ESR spectral data.

\begin{tabular}{|c|c|c|c|c|c|c|}
\hline \multirow{2}{*}{ Complexes } & \multicolumn{2}{|c|}{ Electronic spectra } & \multicolumn{4}{|c|}{ ESR spectral data } \\
\hline & Absorption $\left(\mathrm{cm}^{-1}\right)$ & Band assignment & $g_{\perp}$ & $g_{\|}$ & $g_{\mathrm{avg}}$ & G \\
\hline \multirow{3}{*}[\mathrm{Cu}(\mathrm{C}_{20}\mathrm{H}_{15}\mathrm{N}_{5}\mathrm{OS}_{2})(\mathrm{Cl}_{2})]{} & 9993 & ${ }^{2} \mathrm{~B}_{1} \rightarrow{ }^{2} \mathrm{~A}_{1}\left(v_{1}\right)$ & 2.03 & 2.16 & 2.07 & 5.01 \\
\hline & 14595 & ${ }^{2} \mathrm{~B}_{1} \rightarrow{ }^{2} \mathrm{~B}_{2}\left(v_{2}\right)$ & & & & \\
\hline & 18045 & ${ }^{2} \mathrm{~B}_{1} \rightarrow{ }^{2} \mathrm{E}\left(v_{3}\right)$ & & & & \\
\hline \multirow{3}{*}[\mathrm{Co}(\mathrm{C}_{20}\mathrm{H}_{15}\mathrm{N}_{5}\mathrm{OS}_{2})(\mathrm{Cl}_{2})]{} & 11098 & ${ }^{4} \mathrm{~A}_{2}+{ }^{4} \mathrm{E} \rightarrow{ }^{4} \mathrm{~B}_{1}\left(\nu_{1}\right)$ & & & & \\
\hline & 17675 & ${ }^{4} \mathrm{~A}_{2}+{ }^{4} \mathrm{E} \rightarrow{ }^{4} \mathrm{E}(\mathrm{P})\left(\nu_{2}\right)$ & & & & \\
\hline & 20180 & ${ }^{4} \mathrm{~A}_{2}+{ }^{4} \mathrm{E} \rightarrow{ }^{4} \mathrm{~A}_{2}(\mathrm{P})\left(v_{3}\right)$ & & & & \\
\hline \multirow{3}{*}[\mathrm{Ni}(\mathrm{C}_{20}\mathrm{H}_{15}\mathrm{N}_{5}\mathrm{OS}_{2})(\mathrm{Cl}_{2})]{} & 10000 & ${ }^{3} \mathrm{~B}_{1} \rightarrow{ }^{3} \mathrm{E}^{\mathrm{a}}\left(v_{1}\right)$ & & & & \\
\hline & 13543 & ${ }^{2} \mathrm{~B}_{1} \rightarrow{ }^{3} \mathrm{~A}_{2}\left(v_{2}\right)$ & & & & \\
\hline & 22307 & ${ }^{3} \mathrm{~B}_{1} \rightarrow{ }^{3} \mathrm{E}^{\mathrm{b}}\left(v_{3}\right)$ & & & & \\
\hline
\end{tabular}<smiles>[Y16][Y11]([H])([H])[H]</smiles>

Ćl 'Cl

$m / z 533$ (2.23\%)

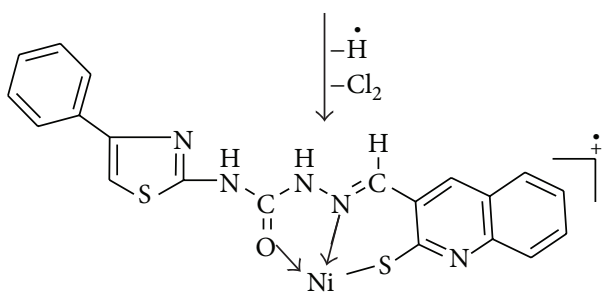

$m / z 462$ (29.92\%)

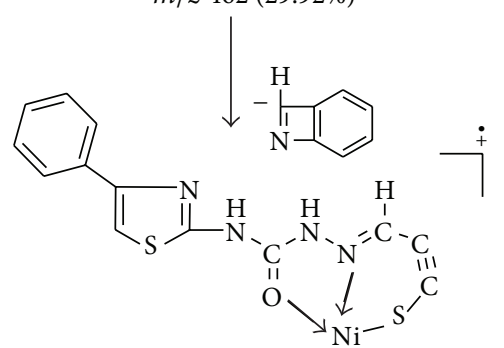

$\mathrm{m} / z 359(3.14 \%)$

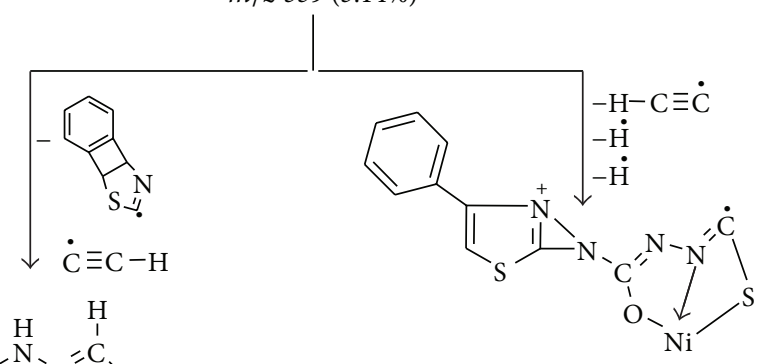<smiles>N[14CH2]N1N[N+]2=CSC[NH+](C2)S1</smiles>

$m / z 332(21.25 \%)$

$m / z 177(100 \%)$

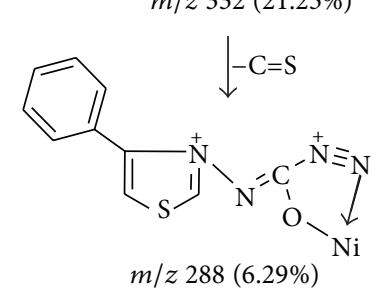

SCHEME 4: Mass fragmentation pattern of Ni(II) complex. 


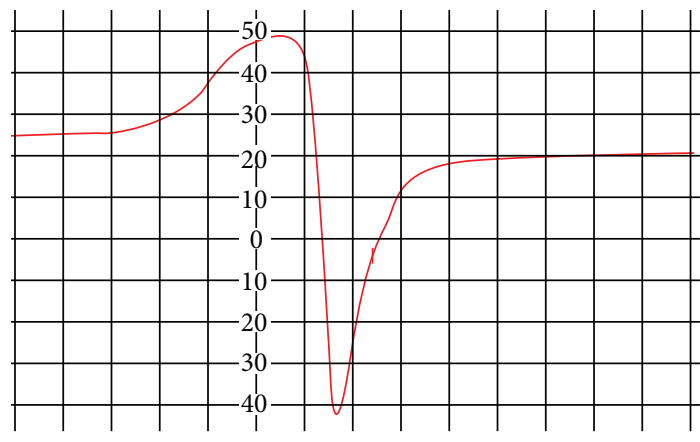

FIgURE 3: ESR spectrum of $\mathrm{Cu}(\mathrm{II})$ complex.

$g$-tensor parameter with $g_{\|}(2.16)>g_{\perp}(2.03)>2.0023$, indicating presence of unpaired electron in $d_{x 2-y 2}$ ground state characteristic of square pyramidal geometry. The averaged " $g$ " value for overall distortion is calculated using the equation: $g_{\text {avg }}=(1 / 3)\left(2 g_{\perp}+g_{\|}\right)$. The exchange interaction parameter $G$ is calculated using the equation: $G=g_{\|}-$ $2.0023 / g_{\perp}-2.0023$. According to Hathaway and Billing [48], if the value of $G$ is more than four, the exchange interaction between the $\mathrm{Cu}$ centres is negligible. In the present case the $G$ value of 5.01 confirms the that exchange interactions between $\mathrm{Cu}(\mathrm{II})$ centers in solid state are negligible [49].

3.6. Thermal Studies. In order to examine the thermal stability of the complexes, thermo gravimetric (TG) and differential thermal analyses (DTA) were carried out for $\mathrm{Cu}(\mathrm{II})$, $\mathrm{Co}(\mathrm{II})$, and $\mathrm{Zn}$ (II) complexes in static air at a temperature range between 40 to $750^{\circ} \mathrm{C}$ at the heating rate of $10^{\circ} \mathrm{C} \mathrm{min}{ }^{-1}$. The proposed stepwise thermal degradation pattern of complexes with temperature and formation of metal oxides is given in Table 4.

3.6.1. $\mathrm{Cu}$ (II) Complex. TGA and DTA curves of $\mathrm{Cu}$ (II) complex (Figure 4) showed that the complex is stable up to $237^{\circ} \mathrm{C}$ and no weight loss is observed before this temperature. The first stage of degradation occurred at $237.6^{\circ} \mathrm{C}$, with the loss of the two chlorine atoms with a practical weight loss of $11.96 \%$ (Calc.12.99\%). The resultant complex on further degradation gave a break at $291^{\circ} \mathrm{C}$ by the loss of NCS species of quinoline moiety with a practical weight loss of $11.41 \%$ (Calc. $12.37 \%$ ). The resultant complex underwent third stage of decomposition at $341^{\circ} \mathrm{C}$ due to loss of $\mathrm{C}_{9} \mathrm{H}_{7}$ molecule of quinoline and $\mathrm{C}_{6} \mathrm{H}_{6}$ molecule of thiazole moiety simultaneously with a practical weight loss of $47.96 \%$ (Calc. 47.01\%). Further, complex showed decomposition up to $493^{\circ} \mathrm{C}$ due to the loss of remaining organic moiety. The final weight of the residue corresponds to cupric oxide.

3.6.2. Co(II) Complex. The thermogram of Co(II) complex showed first stage of decomposition due to loss of NCS species of quinoline moiety at $258^{\circ} \mathrm{C}$ with a practical weight loss of $9.66 \%$ (Calc. 10.86\%). The resultant complex on further degradation gave a break at $320^{\circ} \mathrm{C}$ by the loss of $\mathrm{C}_{8} \mathrm{H}_{6}$ molecule of quinoline moiety with a practical weight loss of $22.22 \%$ (Calc. 21.43\%), which on further degradation gave a break at $458^{\circ} \mathrm{C}$ due to loss of remaining thiazole moiety $\left(\mathrm{C}_{9} \mathrm{H}_{7} \mathrm{~N}_{2} \mathrm{~S}\right)$, two chlorine atoms, and $\mathrm{HC}=\mathrm{N}-\mathrm{N}-\mathrm{NH}$ group simultaneously with a practical weight loss of $78.02 \%$ (Calc. $76.75 \%)$. After this, the complex showed a gradual decomposition up to $697^{\circ} \mathrm{C}$ by the loss of remaining organic moiety. The final weight of the residue corresponds to cobalt oxide.

3.6.3. $\mathrm{Zn}$ (II) Complex. The thermogram of $\mathrm{Zn}$ (II) complex showed first stage of decomposition due to loss of $\mathrm{C}_{6} \mathrm{H}_{7}$ species of thiazole and two chlorine atoms at $270^{\circ} \mathrm{C}$ with a practical weight loss of $28.71 \%$ (Calc. $27.57 \%$ ). This on further loss due to $\mathrm{C}_{10} \mathrm{H}_{6} \mathrm{NS}$ of quinoline and $\mathrm{CH}=\mathrm{CH}$ molecule of thiazole moiety gave a break at $320^{\circ} \mathrm{C}$ with a practical weight loss of $51.58 \%$ (Calc. 50.58\%). After this, the complex showed a gradual decomposition up to $351^{\circ} \mathrm{C}$ by the loss of remaining organic moiety. The final weight of the residue corresponds to respective metal oxide.

3.7. Powder X-Ray Diffraction Studies. The synthesized $\mathrm{Cu}(\mathrm{II}), \mathrm{Co}(\mathrm{II}), \mathrm{Ni}(\mathrm{II})$, and $\mathrm{Zn}(\mathrm{II})$ complexes of Schiff base ligand (L) were soluble in some polar organic solvents (DMSO and DMF). The crystals that are suitable for single crystal studies are not obtained. In order to test the degree of crystallinity of the synthesized metal complexes, we obtained the powder X-ray diffraction pattern of the above complexes. The X-ray diffraction of $\mathrm{Cu}(\mathrm{II}), \mathrm{Co}(\mathrm{II}), \mathrm{Ni}(\mathrm{II})$, and $\mathrm{Zn}$ (II) complexes was scanned in the range $3-80^{\circ}(\theta)$ at wave length $1.54 \AA$. In all the complexes, the trend of the curves decreases from maximum to minimum intensity indicating the amorphous nature of the complexes in the present metal-ligand formation.

The X-ray diffraction pattern of $\mathrm{Cu}(\mathrm{II})$ complex records eight reflections between the range $3-80^{\circ}(2 \theta)$, which arise from diffraction of X-ray by the plane of the complex (Figure 5). The interplanar spacing ( $d$-values) has been calculated by using Bragg's equation: $n \lambda=2 d \sin \theta$. The unit cell calculations have been done for cubic symmetry from the all-important peaks and the methods yielded $h k l$ (Miller indices) unit cell parameter values and depicted in Table 5. The observed interplanar $d$-spacing values have been compared with the calculated ones and found to be in good agreement. The $h^{2}+k^{2}+l^{2}$ values are $1,21,25,37,53,66,81$, and 92 . It was observed that the presence of forbidden number 92 indicates that the $\mathrm{Cu}$ (II) complex may belong to hexagonal or tetragonal system.

The X-ray diffraction pattern of $\mathrm{Ni}(\mathrm{II})$ complex records nine reflections between the range $3-80^{\circ}(2 \theta)$, which arise from diffraction of X-ray by the plane of the complex (Figure 6$)$. The interplanar spacing ( $d$-values) has been calculated by using Bragg's equation: $n \lambda=2 d \sin \theta$. The unit cell calculations have been done for cubic symmetry from the all-important peaks and the methods yielded $h k l$ (Miller indices) unit cell parameter values depicted in Table 6. The observed interplanar $d$-spacing values have been compared with the calculated ones and found to be in good agreement. The $h^{2}+k^{2}+l^{2}$ values are $1,19,23,33,43,47,72,75$, and 78 . It was observed that the presence of forbidden numbers 23 , 43 , and 47 indicates that the $\mathrm{Ni}$ (II) complex may belong to hexagonal or tetragonal system. 
TABle 4: Thermal data of $\mathrm{Cu}(\mathrm{II}), \mathrm{Co}(\mathrm{II})$ and $\mathrm{Zn}$ (II) complex.

\begin{tabular}{|c|c|c|c|c|c|c|}
\hline \multirow{2}{*}{ Complex } & \multirow{2}{*}{ Decomposition temp. $\left({ }^{\circ} \mathrm{C}\right)$} & \multicolumn{2}{|c|}{ Weight loss (\%) } & \multicolumn{2}{|c|}{ Metal oxide (\%) } & \multirow{2}{*}{ Inference } \\
\hline & & Obsd. & Calc. & Obsd. & Calc. & \\
\hline \multirow{4}{*}[\mathrm{Cu}(\mathrm{C}_{20}\mathrm{H}_{15}\mathrm{N}_{5}\mathrm{OS}_{2})(\mathrm{Cl}_{2})]{} & 237.6 & 11.96 & 12.99 & - & - & Loss due to two chlorine atoms \\
\hline & 291 & 11.41 & 12.37 & - & - & Loss due to NCS species \\
\hline & 341 & 47.96 & 47.01 & - & - & $\begin{array}{l}\text { Loss due to } \mathrm{C}_{9} \mathrm{H}_{7} \text { molecule of quinoline } \\
\text { and } \mathrm{C}_{6} \mathrm{H}_{6} \text { molecule of thiazole moiety }\end{array}$ \\
\hline & Up to 493 & - & - & 15.92 & 15.65 & Loss due to remaining organic moiety \\
\hline \multirow{4}{*}[\mathrm{Co}(\mathrm{C}_{20}\mathrm{H}_{15}\mathrm{N}_{5}\mathrm{OS}_{2})(\mathrm{Cl}_{2})]{} & 258 & 9.66 & 10.86 & - & - & Loss due to NCS species \\
\hline & 320 & 22.22 & 21.43 & - & - & $\begin{array}{l}\text { Loss due to } \mathrm{C}_{8} \mathrm{H}_{6} \text { molecule of quinoline } \\
\text { moiety }\end{array}$ \\
\hline & 458 & 78.02 & 76.75 & - & - & $\begin{array}{l}\text { Loss due to } \mathrm{C}_{9} \mathrm{H}_{7} \mathrm{~N}_{2} \mathrm{~S} \text { of thiazole moiety, } \\
\text { two chlorine atoms and } \mathrm{HC}=\mathrm{N}-\mathrm{NH} \\
\text { group }\end{array}$ \\
\hline & Up to 697 & & & 17.15 & 17.56 & Loss due to remaining organic moiety \\
\hline \multirow{3}{*}[\mathrm{Zn}(\mathrm{C}_{20}\mathrm{H}_{15}\mathrm{N}_{5}\mathrm{OS}_{2})(\mathrm{Cl}_{2})]{} & 270 & 28.71 & 27.57 & - & - & $\begin{array}{l}\text { Loss due } \mathrm{C}_{6} \mathrm{H}_{7} \text { species of thiazole and } \\
\text { two chlorine atoms }\end{array}$ \\
\hline & 320 & 51.58 & 50.58 & - & - & $\begin{array}{l}\text { Loss due to } \mathrm{C}_{10} \mathrm{H}_{6} \mathrm{NS} \text { molecule of } \\
\text { quinoline and } \mathrm{CH}=\mathrm{CH} \text { molecule of } \\
\text { thiazole moiety }\end{array}$ \\
\hline & Up to 351 & - & - & 16.25 & 17.13 & Loss due to remaining organic moiety \\
\hline
\end{tabular}

TABle 5: Powder X-ray data of $\mathrm{Cu}(\mathrm{II})$ complex.

\begin{tabular}{|c|c|c|c|c|c|c|c|c|c|c|}
\hline \multirow[b]{2}{*}{ Peak } & \multirow[b]{2}{*}{$2 \theta$} & \multirow[b]{2}{*}{$\theta$} & \multirow[b]{2}{*}{$\sin \theta$} & \multirow[b]{2}{*}{$\sin ^{2} \theta$} & \multirow[b]{2}{*}{$1000 \sin ^{2} \theta$} & \multirow{2}{*}{$\begin{array}{l}1000 \sin ^{2} \theta / \mathrm{CF} \\
\left(h^{2}+k^{2}+l^{2}\right)\end{array}$} & \multirow[b]{2}{*}{$h k l$} & \multicolumn{2}{|c|}{$d$} & \multirow[b]{2}{*}{$a$ in $\AA$} \\
\hline & & & & & & & & Obs. & Calc. & \\
\hline 1 & 5.758 & 2.879 & 0.050 & 0.0025 & 2.52 & $1.00(1)$ & $\left(\begin{array}{lll}1 & 0 & 0\end{array}\right)$ & 15.335 & 15.338 & 15.330 \\
\hline 2 & 26.804 & 13.402 & 0.231 & 0.0536 & 53.68 & $21.301(21)$ & $\left(\begin{array}{lll}4 & 2 & 1\end{array}\right)$ & 3.323 & 3.323 & 15.338 \\
\hline 3 & 28.790 & 14.395 & 0.248 & 0.0618 & 61.80 & $24.523(25)$ & $\left(\begin{array}{lll}4 & 3 & 0\end{array}\right)$ & 3.098 & 3.097 & 15.338 \\
\hline 4 & 35.480 & 17.74 & 0.304 & 0.0927 & 92.78 & $36.817(37)$ & $\left(\begin{array}{lll}6 & 1 & 0\end{array}\right)$ & 2.528 & 2.527 & 15.338 \\
\hline 5 & 42.777 & 21.388 & 0.364 & 0.1329 & 132.93 & $52.750(53)$ & 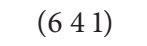 & 2.112 & 2.111 & 15.338 \\
\hline 6 & 48.302 & 24.151 & 0.409 & 0.1673 & 167.36 & $66.412(66)$ & $(554)$ & 1.882 & 1.882 & 15.338 \\
\hline 7 & 53.771 & 26.885 & 0.452 & 0.2044 & 204.48 & $81.142(81)$ & $(8 \quad 41)$ & 1.703 & 1.702 & 15.338 \\
\hline 8 & 57.486 & 28.743 & 0.480 & 0.2311 & 231.16 & $91.733(92)$ & $(---)$ & 1.601 & 1.601 & 15.339 \\
\hline
\end{tabular}

TABLE 6: Powder X-ray data of Ni(II) complex.

\begin{tabular}{lcccccccccc}
\hline Peak & $2 \theta$ & $\theta$ & $\sin \theta$ & $\sin ^{2} \theta$ & $1000 \sin ^{2} \theta$ & $\begin{array}{c}1000 \sin ^{2} \theta / \mathrm{CF} \\
\left(h^{2}+k^{2}+l^{2}\right)\end{array}$ & $h k l$ & $\begin{array}{c}d \\
\text { Obs. }\end{array}$ \\
\hline 1 & 6.099 & 3.049 & 0.053 & 0.0028 & 2.83 & $1.00(1)$ & $(100)$ & 14.480 & 14.476 & 14.474 \\
2 & 26.903 & 13.451 & 0.232 & 0.0541 & 54.11 & $19.120(19)$ & $(331)$ & 3.311 & 3.310 & 14.475 \\
3 & 29.603 & 14.801 & 0.255 & 0.0652 & 65.26 & $23.061(23)$ & $(---)$ & 3.015 & 3.014 & 14.481 \\
4 & 35.529 & 17.764 & 0.305 & 0.0930 & 93.08 & $32.892(33)$ & $(522)$ & 2.524 & 2.523 & 14.480 \\
5 & 40.704 & 20.352 & 0.347 & 0.1209 & 120.95 & $42.738(43)$ & $(---)$ & 2.214 & 2.214 & 14.477 \\
6 & 42.874 & 21.437 & 0.365 & 0.1335 & 133.57 & $47.197(47)$ & $(---)$ & 2.107 & 2.107 & 14.477 \\
7 & 53.747 & 26.873 & 0.452 & 0.2043 & 204.32 & $72.196(72)$ & $(660)$ & 1.704 & 1.703 & 14.474 \\
8 & 54.889 & 27.444 & 0.460 & 0.2124 & 212.418 & $75.057(75)$ & $(751)$ & 1.671 & 1.671 & 14.474 \\
9 & 56.054 & 28.027 & 0.469 & 0.2207 & 220.794 & $78.016(78)$ & $(752)$ & 1.639 & 1.638 & 14.477 \\
\hline
\end{tabular}




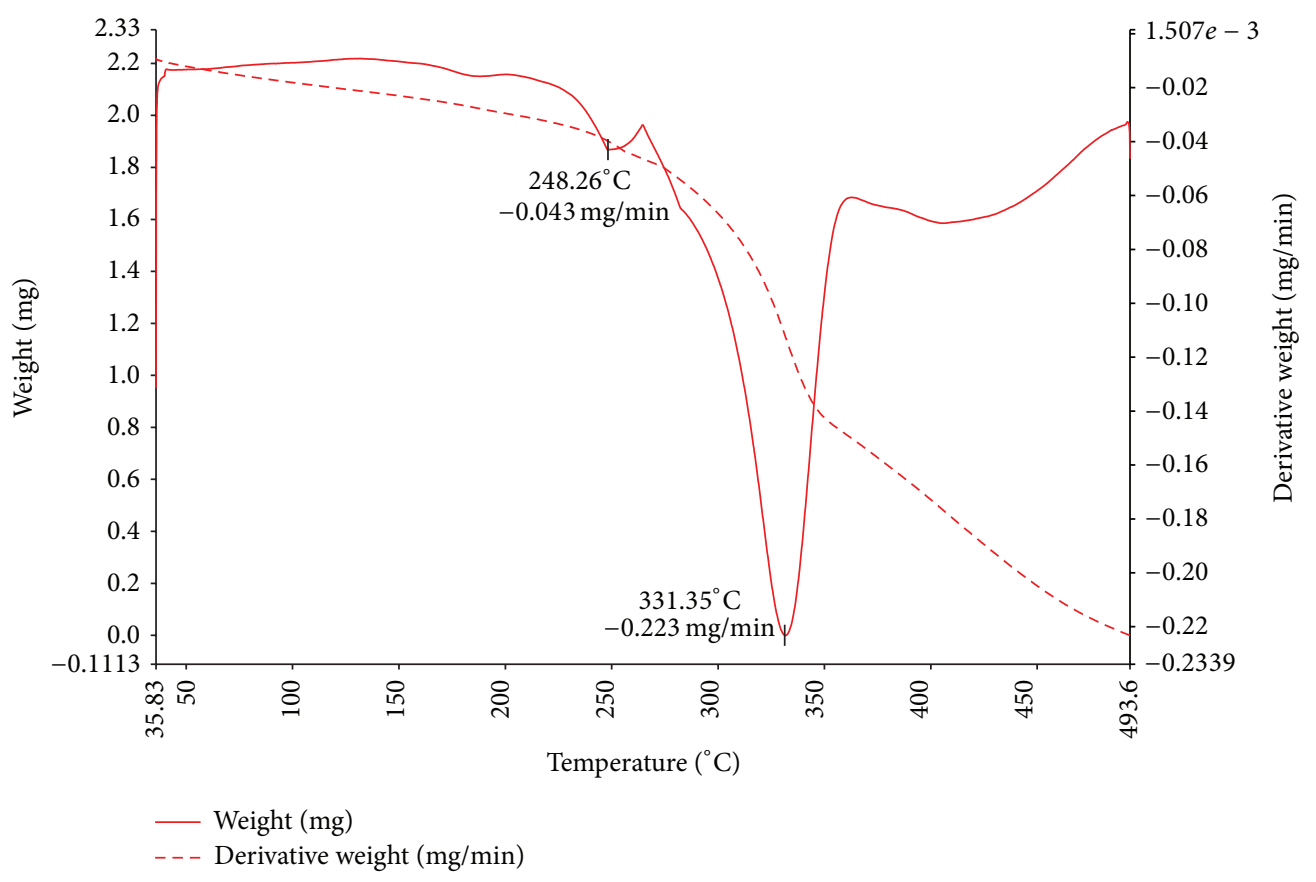

FIgURE 4: TGA and DTA curve of $\mathrm{Cu}(\mathrm{II})$ complex.

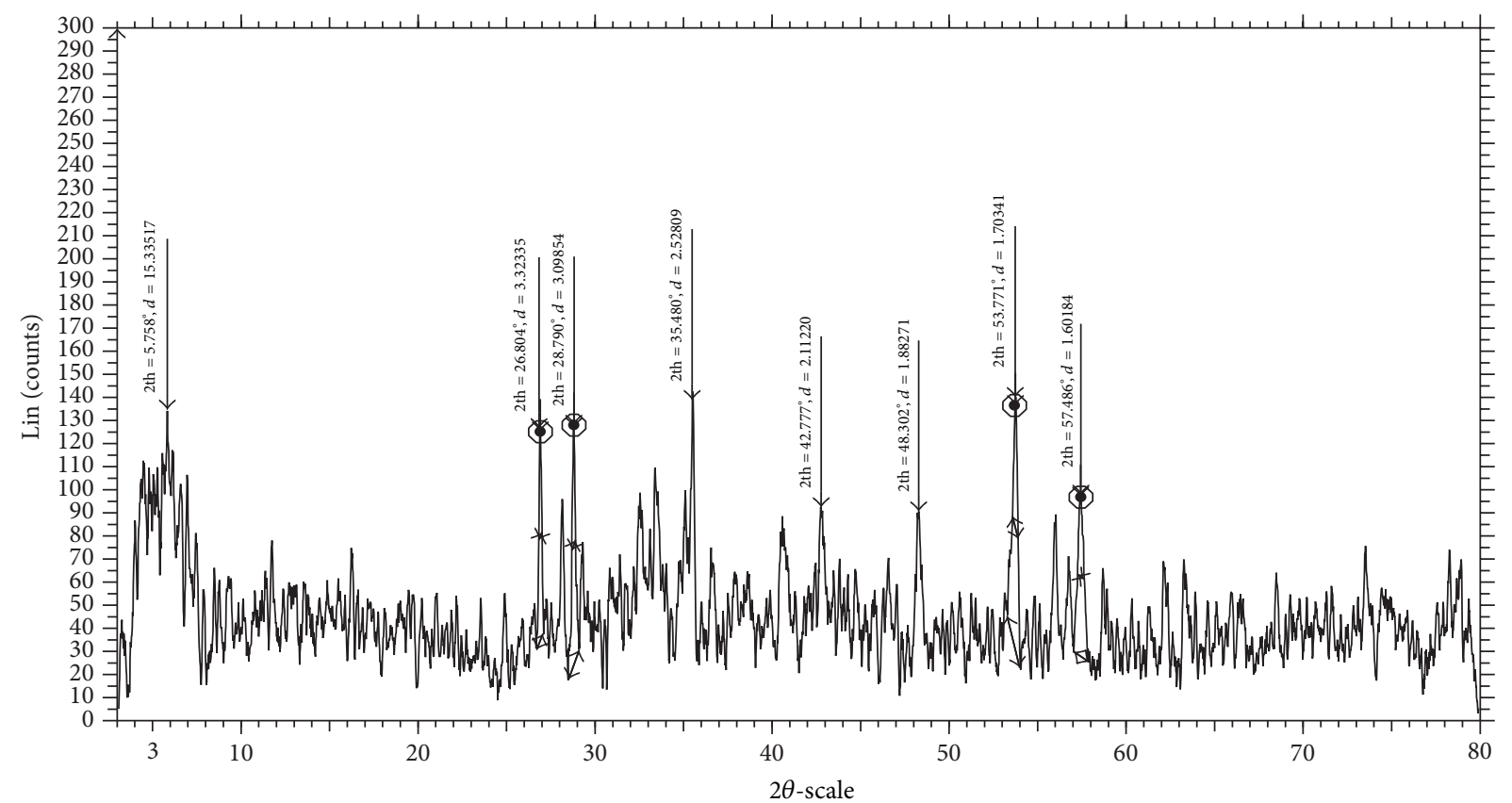

Figure 5: Powder XRD spectrum of $\mathrm{Cu}(\mathrm{II})$ complex.

Similar calculations were done for $\mathrm{Co}(\mathrm{II})$ and $\mathrm{Zn}$ (II) complexes. The Co(II) complex showed seven reflections and $\mathrm{Zn}$ (II) complex showed five reflections between the range 3$80^{\circ}(2 \theta)$. For all the complexes, the interplanar spacing $(d$ values) and unit cell calculations have been done for cubic symmetry from the all-important peaks and the method yielded $h k l$ (Miller indices) units cell parameter values. The $h^{2}+k^{2}+l^{2}$ values for Co(II) complex are $1,5,7$, and 10 and for the $\mathrm{Zn}$ (II) complex 1, 2, 29, 37, and 63, respectively. It was observed that the presence of forbidden number 7 in
Co(II) complex and forbidden number 63 in $\mathrm{Zn}$ (II) complex, respectively, indicates that these complexes may belong to hexagonal or tetragonal system.

\subsection{Biological Evaluation}

3.8.1. In Vitro Antibacterial and Antifungal Activities. The in vitro antimicrobial activity of all the synthesized compounds was screened against Enterobacter aerogenes and Pseudomonas aeruginosa bacteria and Aspergillus niger and 


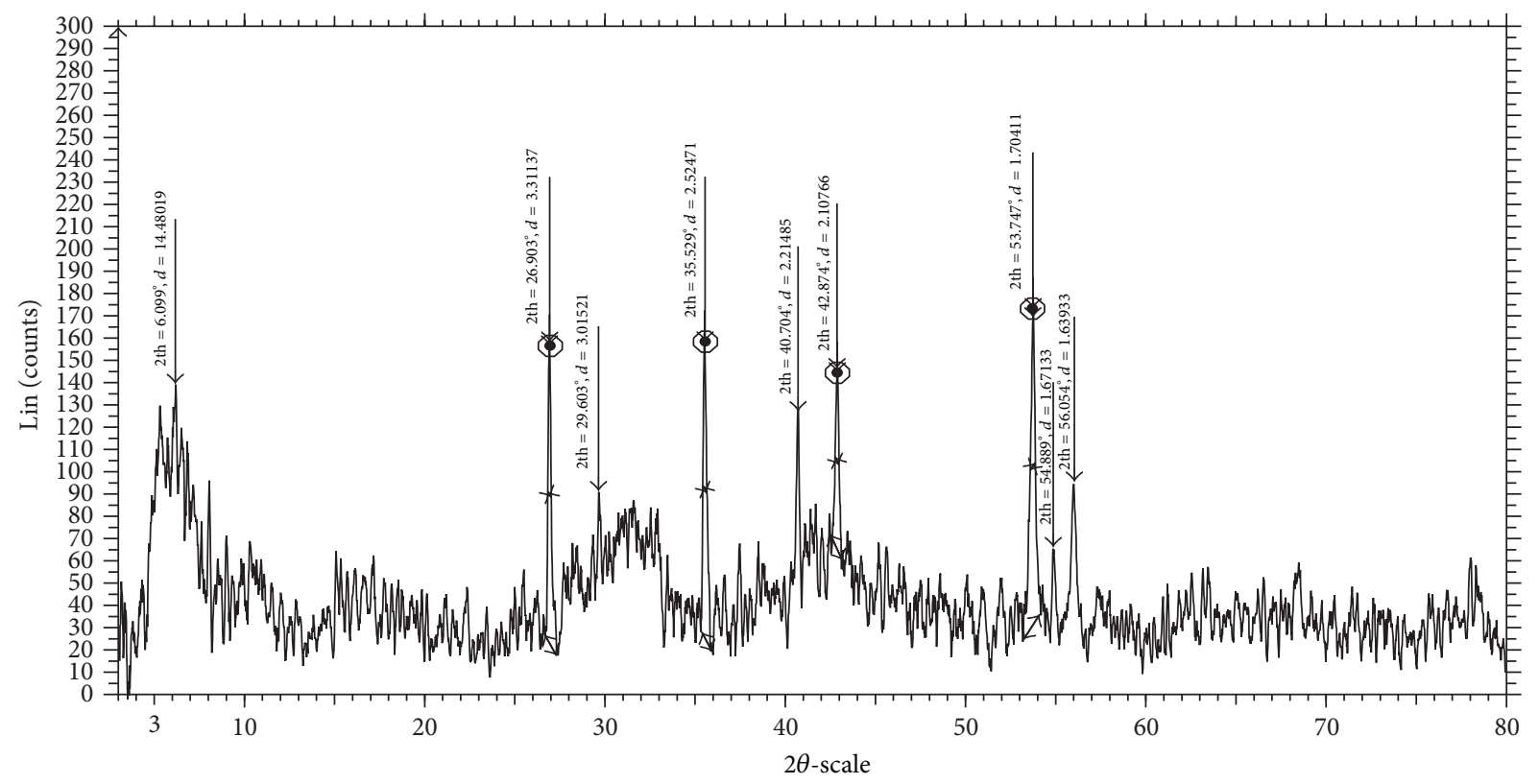

FIgure 6: Powder XRD spectrum of Ni(II) complex.

Aspergillus flavus fungal strains by minimum inhibitory concentration (MIC) method. The minimum inhibitory concentration (MIC) profiles of all the compounds against bacteria and fungi are summarized in Table 7.

The MIC values indicated that all the complexes exhibited promising results compared to the ligand against mentioned microorganisms, and this activity is found to be enhanced on coordination with the metal ions. This enhancement in the activity may be rationalized on the basis that ligands mainly possess $\mathrm{C}=\mathrm{N}$ bond. The enhanced activity of the complexes over the ligand can be explained on the basis of chelation theory $[50,51]$. It is observed that, in a complex, the positive charge of the metal is partially shared with the donor atoms present in the ligand, and there may be $\pi$-electron delocalization over the whole chelate [52]. This increases the lipophilic character of the metal chelate and favors its permeation through the lipoid layer of the bacterial membranes. The heterocyclic Schiff bases with different functional groups have greater tendency to interact with nucleoside bases even after complexation with metal ion or with the essential metal ions present in the biosystem can act as a promising bactericides because they always tend to interact with enzymatic functional groups in order to achieve higher coordination numbers [53]. There are also other factors which increase the activity, namely, solubility, conductivity, and bond length between the metal and the ligand.

3.8.2. DNA Cleavage Activity. The interaction of plasmid pBR322 DNA with newly synthesized ligand $\mathbf{L}$ and its $\mathrm{Cu}(\mathrm{II})$, $\mathrm{Co}(\mathrm{II}), \mathrm{Ni}(\mathrm{II})$, and $\mathrm{Zn}$ (II) complexes was studied using agarose gel electrophoresis method. The gel picture showing the cleavage of plasmid pBR322 DNA is depicted in Figure 7. The characterization of DNA recognition by transition metal complex has been aided by the DNA cleavage chemistry associated with redox-active or photo activated metal complexes [54]. The electrophoresis analysis clearly revealed that

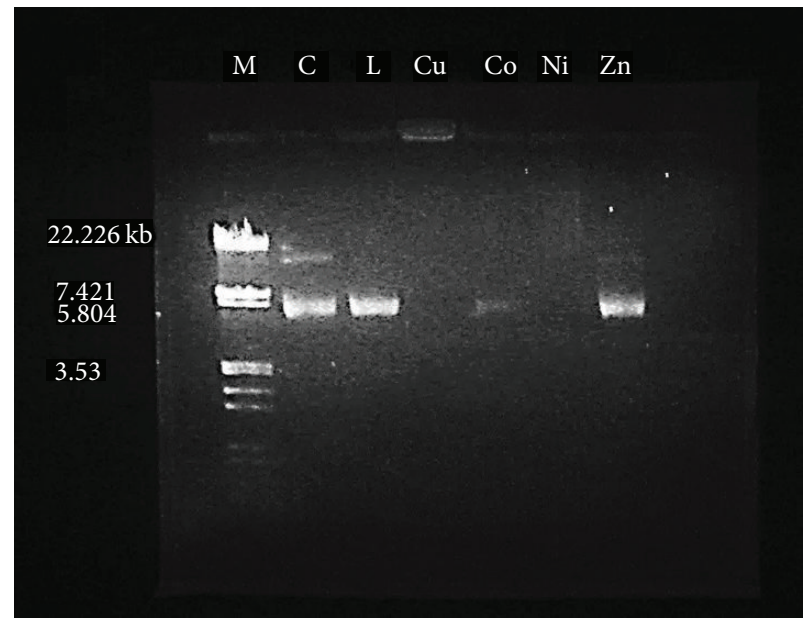

FIGURE 7: DNA cleavage on plasmid pBR 322: M: Standard DNA, C: Control DNA (untreated pBR 322), L: Schiff base ligand, $\mathrm{Cu}: \mathrm{Cu}(\mathrm{II})$ complex, Co: Co(II) complex, Ni: Ni(II) complex, and Zn: Zn(II) complex.

the ligand and its metal complexes have acted on DNA because of a difference in molecular weight between the control and the treated DNA samples. The difference was observed in the bands of lanes of complexes compared with the control DNA of pBR322 due to the relaxation of circular DNA into linear form. This shows that the control DNA alone does not show any apparent cleavage, whereas the ligand and its metal complexes do show. In the present study, the Ethedium bromide (EtBr) stained banding pattern of plasmid pBR322 DNA was tested with newly synthesized ligand and its metal complexes. In the present case, the ligand and its $\mathrm{Cu}(\mathrm{II}), \mathrm{Co}(\mathrm{II})$, and $\mathrm{Zn}$ (II) complex showed complete cleavage of super coiled DNA and the $\mathrm{Ni}$ (II) complex showed 
TABLE 7: Minimum Inhibitory Concentration (MIC in $\mu \mathrm{g} / \mathrm{mL}$ ) of Schiff base ligand (L) and its metal complexes.

\begin{tabular}{|c|c|c|c|c|c|c|c|c|c|c|c|}
\hline \multirow{2}{*}{ Organisms } & \multicolumn{11}{|c|}{ Concentration $(\mu \mathrm{g} / \mathrm{mL})$} \\
\hline & Compounds & 0.195 & 0.39 & 0.78 & 1.563 & 3.125 & 6.25 & 12.50 & 25 & 50 & 100 \\
\hline \multirow{5}{*}{$\begin{array}{l}\text { Enterobacter } \\
\text { Aerogenes }\end{array}$} & Ligand (L) & + & + & + & + & $* * *$ & - & - & - & - & - \\
\hline & Cu-Complex & + & + & + & $* * *$ & - & - & - & - & - & - \\
\hline & Co-Complex & + & + & + & $* * *$ & - & - & - & - & - & - \\
\hline & Ni-Complex & + & + & + & + & $* * *$ & - & - & - & - & - \\
\hline & Zn-Complex & + & + & + & $* * *$ & - & - & - & - & - & - \\
\hline \multirow{5}{*}{$\begin{array}{l}\text { Pseudomonas } \\
\text { aerugenosa }\end{array}$} & Ligand (L) & + & + & + & + & + & $* * *$ & - & - & - & - \\
\hline & Cu-Complex & + & + & $* * *$ & - & - & - & - & - & - & - \\
\hline & Co-Complex & + & + & $* * *$ & - & - & - & - & - & - & - \\
\hline & Ni-Complex & + & + & + & $* * *$ & - & - & - & - & - & - \\
\hline & Zn-Complex & + & + & $* * *$ & - & - & - & - & - & - & - \\
\hline \multirow{5}{*}{$\begin{array}{l}\text { Aspergillus } \\
\text { niger }\end{array}$} & Ligand (L) & + & + & + & + & + & + & $* * *$ & - & - & - \\
\hline & $\mathrm{Cu}$-Complex & + & + & + & $* * *$ & - & - & - & - & - & - \\
\hline & Co-Complex & + & + & + & + & + & $* * *$ & - & - & - & - \\
\hline & Ni-Complex & + & + & + & $* * *$ & - & - & - & - & - & - \\
\hline & Zn-Complex & + & + & + & + & $* * *$ & - & - & - & - & - \\
\hline \multirow{5}{*}{$\begin{array}{l}\text { Aspergillus } \\
\text { flavus }\end{array}$} & Ligand (L) & + & + & + & + & + & $* * *$ & - & - & - & - \\
\hline & $\mathrm{Cu}$-Complex & + & + & + & + & $* * *$ & - & - & - & - & - \\
\hline & Co-Complex & + & + & + & + & + & + & + & $* * *$ & - & - \\
\hline & Ni-Complex & + & + & + & + & $* * *$ & - & - & - & - & - \\
\hline & Zn-Complex & + & + & + & + & $* * *$ & - & - & - & - & - \\
\hline
\end{tabular}

${ }^{+}$indicates turbidity is observed.

${ }^{-}$indicates turbidity is not observed.

*** represents the MIC value.

TABLE 8: Brine shrimp bioassay data of the Schiff base ligand (L) and its metal complexes.

\begin{tabular}{lc}
\hline Compound & $\mathrm{LD}_{50}(\mathrm{M} / \mathrm{mL})$ \\
\hline Ligand $(\mathrm{L})$ & $2.470 \times 10^{-4}$ \\
Cu-Complex & $1.387 \times 10^{-4}$ \\
Co-Complex & $1.168 \times 10^{-4}$ \\
Ni-Complex & $1.074 \times 10^{-4}$ \\
Zn-Complex & $2.308 \times 10^{-4}$ \\
\hline
\end{tabular}

partial cleavage of relaxed DNA and complete cleavage of supercoiled DNA. This clearly reveals the important role of coordination of $\mathrm{O}, \mathrm{N}$, and $\mathrm{S}$ groups to the metal ion in these DNA cleavage activities. On the basis of these findings, it can be concluded that all the newly synthetized compounds under present study are good pathogenic microorganism inhibitor; as evident on the DNA cleavage of pBR322.

3.8.3. In Vitro Cytotoxicity. All the synthesized compounds were screened for their cytotoxicity (brine shrimp bioassay) using the protocol of Meyer et al. [38]. From the data recorded in Table 8 , it is evident that all the newly synthesized metal complexes exhibited potent activity when compared to the free ligand. The $\mathrm{Co}(\mathrm{II})$ and $\mathrm{Ni}$ (II) complexes displayed significant potent cytotoxic activity as $\mathrm{LD}_{50}=1.168 \times 10^{-4}$ and $1.074 \times 10^{-4} \mathrm{M} / \mathrm{mL}$, respectively, against Artemia salina.<smiles>O=C(NC(=S)N=Cc1cc2ccccc2[nH]c1=S)Nc1nc(-c2ccccc2)cs1</smiles>

$\mathrm{M}=\mathrm{Cu}(\mathrm{II}), \mathrm{Co}(\mathrm{II}), \mathrm{Ni}(\mathrm{II})$, and $\mathrm{Zn}(\mathrm{II})$

FIgURE 8: Proposed structure of the complexes.

\section{Conclusions}

The newly synthesized Schiff base ligand $N$-(4-phenylthiazol-2yl)-2-((2-thiaxo-1,2-dihydroquinolin-3-yl)methylene)hydrazinecarboxamide behaves as tridentate ONS donor and forms the complexes of type $\left[\mathrm{ML}(\mathrm{Cl})_{2}\right]$. With the help of various physicochemical and spectroscopic methods such as IR, ${ }^{1} \mathrm{H}$ NMR, UV-Visible, and ESR, the square pyramidal geometries of the $\mathrm{Cu}(\mathrm{II}), \mathrm{Co}(\mathrm{II}), \mathrm{Ni}(\mathrm{II})$, and $\mathrm{Zn}$ (II) complexes have been proposed (Figure 8). The newly synthesized metal complexes showed good antimicrobial activity when compared to the free ligand. The DNA cleavage activity 
of all the synthesized compounds showed the cleavage of plasmid DNA pBR 322 and the cytotoxicities of $\mathrm{Co}(\mathrm{II})$ and $\mathrm{Ni}(\mathrm{II})$ complexes indicate potent cytotoxic agents that might become potent anticancer agent in clinical trials.

\section{Conflict of Interests}

The authors do not have any agreement, financial assistance, or sponsorship from any institution except providing the data which are of purely academic interest and to encourage young researchers in India. The IR spectra of compounds were recorded on Perkin Elmer-Spectrum RX-I FTIR spectrophotometer using $\mathrm{KBr}$ disc technique, ${ }^{1} \mathrm{H}$ NMR spectra were recorded on Bruker Avance II $400 \mathrm{MHz}$ NMR Spectrometer in $d_{6}$-DMSO using TMS as an internal standard, ESI mass spectra were recorded by electrospray ionization (ESI) on a Waters Micromass Q-Tof Micro spectrometer, ESR spectrum was recorded on JES-FA200 ESR spectrometer, and so forth. These names are mentioned in the experimental protocol as these are the instrument models, and it is mandatory for authors to mention the instrument models used to scan the spectra of unknown compounds. Otherwise, the corresponding author or coauthor has no-direct financial relationship with the commercial identity in any form of the institutes mentioned in our paper.

\section{Acknowledgments}

Authors are thankful to the Professor and Chairman of Department of Chemistry, Gulbarga University, Gulbarga, for providing necessary facilities for research. Authors extend their thanks to SAIF Punjab University, Chandigarh, for providing FT-IR, ${ }^{1} \mathrm{H}$ NMR and ESI mass spectral data, IIT Bombay for providing ESR spectral data, and STIC Cochin University for providing TG/DTA and powder X-ray data. Authors are also thankful to BioGenics Research and Training Centre in Biotechnology, Hubli, for biological studies. One of the authors (Nagesh G. Yernale) is grateful to Department of Science and Technology (DST), New Delhi, for the award of DST-INSPIRE Research fellowship.

\section{References}

[1] P. A. Vigato and S. Tamburini, "The challenge of cyclic and acyclic Schiff bases and related derivatives," Coordination Chemistry Reviews, vol. 248, no. 17-20, pp. 1717-2128, 2004.

[2] N. K. Kaushik and A. K. Mishra, "Synthesis, characterization and thermal studies of some new organotin (IV) complexes with aniline $\mathrm{N}$-thiohydrazide and benzaldehyde aniline $\mathrm{N}$-thiohydrazone," Indian Journal of Chemistry A, vol. 42, no. 11, pp. 27622766, 2003.

[3] M. S. Saraiva, S. Quintal, F. C. M. Portugal et al., "Nitrogen donor ligands bearing N-H groups: effect on catalytic and cytotoxic activity of molybdenum $\eta^{3}$-allyldicarbonyl complexes," Journal of Organometallic Chemistry, vol. 693, no. 21-22, pp. 3411-3418, 2008.

[4] N. K. Singh, A. Srivastava, A. Sodhi, and P. Ranjan, "In vitro and in vivo antitumour studies of a new thiosemicarbazide derivative and its complexes with 3D-metal ions," Transition Metal Chemistry, vol. 25, no. 2, pp. 133-140, 2000.

[5] Y. K. Vaghasiya, R. Nair, M. Soni, S. Baluja, and S. Chanda, "Synthesis, structural determination and antibacterial activity of compounds derived from vanillin and 4-aminoantipyrine," Journal of the Serbian Chemical Society, vol. 69, no. 12, pp. 991998, 2004.

[6] M. E. Hossain, M. N. Alam, J. Begum et al., "The preparation, characterization, crystal structure and biological activities of some copper(II) complexes of the 2-benzoylpyridine Schiff bases of S-methyl- and S-benzyldithiocarbazate," Inorganica Chimica Acta, vol. 249, no. 2, pp. 207-213, 1996.

[7] V. E. Kuz'min, A. G. Artemenko, R. N. Lozytska et al., "Investigation of anticancer activity of macrocyclic Schiff bases by means of 4D-QSAR based on simplex representation of molecular structure," SAR and QSAR in Environmental Research, vol. 16, no. 3, pp. 219-230, 2005.

[8] C. T. Supuran, M. Barboiu, C. Luca, E. Pop, M. E. Brewster, and A. Dinculescu, "Carbonic anhydrase activators. Part 14. Syntheses of mono and bis pyridinium salt derivatives of 2-amino-5-(2-aminoethyl)- and 2-amino-5-(3-aminopropyl)1,3,4-thiadiazole and their interaction with isozyme II," European Journal of Medicinal Chemistry, vol. 31, no. 7-8, pp. 597606, 1996.

[9] D. Branowska, A. A. Farahat, A. Kumar et al., "Synthesis and antiprotozoal activity of 2,5-bis[amidinoaryl]thiazoles," Bioorganic \& Medicinal Chemistry, vol. 18, no. 10, pp. 3551-3558, 2010.

[10] F. Rahaman, B. Hiremath, S. M. Basavarajaiah, B. H. M. Jayakumarswamy, and B. H. M. Mruthyunjayaswamy, "Synthetic, spectral, thermal and antimicrobial activity studies of some transition metal complexes derived from 2-hydroxy-methylbenzaldehyde N-(4' -phenyl-1' $3^{\prime}$-thiazol-2' -yl)semicarbazone," Journal of the Indian Chemical Society, vol. 85, no. 4, pp. 381-386, 2008.

[11] B. S. Holla, K. V. Malini, B. S. Rao, B. K. Sarojini, and N. S. Kumari, "Synthesis of some new 2,4-disubstituted thiazoles as possible antibacterial and anti-inflammatory agents," European Journal of Medicinal Chemistry, vol. 38, no. 3, pp. 313-318, 2003.

[12] V. Banewar, "Green synthesis and in vitro biological evaluation of heteroaryl chalcones and pyrazolines of medicinal interest," Journal of Chemistry, vol. 2013, Article ID 542973, 4 pages, 2013.

[13] A. Andreani, M. Granaiola, A. Leoni, A. Locatelli, R. Morigi, and M. Rambaldi, "Synthesis and antitubercular activity of imidazo[2,1-b]thiazoles," European Journal of Medicinal Chemistry, vol. 36, no. 9, pp. 743-746, 2001.

[14] E. M. Hodnett and P. D. Mooney, "Antitumor activities of some Schiff bases," Journal of Medicinal Chemistry, vol. 13, no. 4, p. 786, 1970.

[15] G. S. Hassan, S. M. El-Messery, F. A. Al-Omary, and H. I. ElSubbagh, "Substituted thiazoles VII. Synthesis and antitumor activity of certain 2-(substituted amino)-4-phenyl-1, 3-thiazole analogs," Bioorganic \& Medicinal Chemistry Letters, vol. 22, no. 20, pp. 6318-6323, 2012.

[16] R. K. Robins and G. H. Hitchings, "Studies on condensed pyrimidine systems. XIX. A new synthesis of pyrido[2,3-d]pyrimidines. The condensation of 1,3-diketones and 3-ketoaldehydes with 4-aminopyrimidines," Journal of the American Chemical Society, vol. 80, no. 13, pp. 3449-3457, 1958.

[17] A. H. M. Raeymaekers, F. T. N. Allewijn, J. Vandenberk, P. J. A. Demoen, T. T. T. van Offenwert, and P. A. J. Janssen, "Novel 
broad-spectrum anthelmintics. Tetramisole and related derivatives of 6-arylimidazo[2,1-b]thiazole," Journal of Medicinal Chemistry, vol. 9, no. 4, pp. 545-551, 1966.

[18] S. R. Pattan, C. Suresh, V. D. Pujar, V. V. K. Reddy, V. P. Rasal, and B. C. Koti, "Synthesis and antidiabetic activity of 2-amino [5' (4- sulphonylbenzylidine)-2,4-thiazolidinedione]-7-chloro6-fluorobenzothiazole," Indian Journal of Chemistry B, vol. 44, no. 11, pp. 2404-2408, 2005.

[19] S. Samadhiya and A. Halve, "Synthetic utility of Schiff bases as potential herbicidal agents," Oriental Journal of Chemistry, vol. 17, pp. 119-122, 2001.

[20] Z.-H. Yu and D.-Q. Shi, "Synthesis and herbicidal activity of amino phosphonate derivatives containing thiazole and pyrazole moieties," Phosphorus, Sulfur and Silicon and the Related Elements, vol. 185, no. 8, pp. 1746-1752, 2010.

[21] M.-G. Kayirere, A. Mahamoud, J. Chevalier, J.-C. Soyfer, A. Crémieux, and J. Barbe, "Synthesis and antibacterial activity of new 4-alkoxy, 4-aminoalkyl and 4-alkylthioquinoline derivatives," European Journal of Medicinal Chemistry, vol. 33, no. 1, pp. 55-63, 1998.

[22] R. Musiol, J. Jampilek, V. Buchta et al., "Antifungal properties of new series of quinoline derivatives," Bioorganic \& Medicinal Chemistry, vol. 14, no. 10, pp. 3592-3598, 2006.

[23] J. H. Burckhalter and W. H. Edgerton, "A new type of 8-quinolinol amebacidal agent," Journal of the American Chemical Society, vol. 73, no. 10, pp. 4837-4839, 1951.

[24] M. Jain, S. I. Khan, B. L. Tekwani et al., "Synthesis, antimalarial, antileishmanial, and antimicrobial activities of some 8-quinolinamine analogues," Bioorganic \& Medicinal Chemistry, vol. 13, no. 14, pp. 4458-4466, 2005.

[25] W. Cunico, C. A. Cechinel, H. G. Bonacorso et al., "Antimalarial activity of 4-(5-trifluoromethyl-1H-pyrazol-1-yl)-chloroquine analogues," Bioorganic and Medicinal Chemistry Letters, vol. 16, no. 3, pp. 649-653, 2006.

[26] Y.-L. Chen, C.-J. Huang, Z.-Y. Huang et al., "Synthesis and antiproliferative evaluation of certain 4-anilino-8-methoxy- 2phenylquinoline and 4-anilino-8-hydroxy-2-phenylquinoline derivatives," Bioorganic \& Medicinal Chemistry, vol. 14, no. 9, pp. 3098-3105, 2006.

[27] C. Papageorgiou, A. Von Matt, J. Joergensen et al., "Aromatic quinolinecarboxamides as selective, orally active antibody production inhibitors for prevention of acute xenograft rejection," Journal of Medicinal Chemistry, vol. 44, no. 12, pp. 1986-1992, 2001.

[28] H. Shinkai, T. Ito, T. Iida, Y. Kitao, H. Yamada, and I. Uchida, “4aminoquinolines: novel nociceptin antagonists with analgesic activity," Journal of Medicinal Chemistry, vol. 43, no. 24, pp. 4667-4677, 2000.

[29] C. H. Kaschula, T. J. Egan, R. Hunter et al., "Structure-activity relationships in 4-aminoquinoline antiplasmodials. The role of the group at the 7-position," Journal of Medicinal Chemistry, vol. 45, no. 16, pp. 3531-3539, 2002.

[30] N. Muruganantham, R. Sivakumar, N. Anbalagan, V. Gunasekaran, and J. T. Leonard, "Synthesis, anticonvulsant and antihypertensive activities of 8-substituted quinoline derivatives," Biological and Pharmaceutical Bulletin, vol. 27, no. 10, pp. 16831687, 2004.

[31] B. H. M. Mruthyunjayaswamy and S. M. Basavarajaiah, "Synthesis and antimicrobial activity of novel ethyl-5-(ethoxycarbonyl)- 4methylthiazol-2-yl-carbamate compounds," Indian Journal of Chemistry B, vol. 48, no. 9, pp. 1274-1278, 2009.
[32] D. B. Vivekanand and B. H. M. Mruthyunjayaswamy, "Synthesis characterization and antimicrobial activity studies of some transition metal complexes derived from 5-chloro-3phenyl-N1-((2-thioxo-1, 2-dihydroquinoline-3-yl)methylene)$1 H$-indole-2-carbohydrazide," International Journal of Chemical Science and Research, vol. 2, pp. 29-48, 2012.

[33] J. Mendham, R. C. Denney, J. D. Barnes, and M. J. K. Thomas, Vogel's Quantitative Chemical Analysis, Prentice Hall, London, UK, 6th edition, 1999.

[34] M. R. Karekal and B. H. M. Mruthyunjayaswamy, "Synthesis, spectroscopic characterization, and biological screening of binuclear transition metal complexes of bicompartmental Schiff bases containing indole and resorcinol moieties," Turkish Journal of Chemistry, vol. 37, pp. 775-795, 2013.

[35] L. L. Ramesh, M. K. Umesh, S. Kirankumar, and V. H. Jayashree, "Phytochemical screening and in vitro antimicrobial activity of Typha angustifolia Linn leaves extract against pathogenic gram negative microorganisms," Journal of Pharmacy Research, vol. 6, pp. 280-283, 2013.

[36] NCCLS (National Committee for Clinical Laboratory Standards), Performance Standards for Antimicrobial Disc Susceptibility Test, Approved Standard M2-A6, NCCLS, Wayne, Pa, USA, 6th edition, 1997.

[37] J. Sambrook, E. F. Fritsch, and T. Maniatis, Molecular Cloning, a Laboratory Manual, Cold Spring Harbor, New York, NY, USA, 2nd edition, 1989.

[38] B. N. Meyer, N. R. Ferrigni, and J. E. Putnam, "Brine shrimp: a convenient general bioassay for active plant constituents," Planta Medica, vol. 45, no. 1, pp. 31-34, 1982.

[39] D. J. Finney, Probit Analysis, Cambridge University Press, Cambridge, UK, 3rd edition, 1971.

[40] F. Rahaman, O. B. Ijare, Y. Jadegoud, and B. H. M. Mruthyunjayaswamy, "Phenoxo-bridged symmetrical homobinuclear complexes derived from an "end-off" compartmental ligand, 2,6-bis $\left[5^{\prime}\right.$-chloro- $3^{\prime}$-phenyl- $1 H$-indole- $2^{\prime}$-carboxamidyliminomethyl]-4-methylphenol," Journal of Coordination Chemistry, vol. 62, no. 9, pp. 1457-1467, 2009.

[41] U. B. Gangadharmath, V. K. Revankar, and V. B. Mahale, "Synthesis and spectroscopic characterization of cationic mononuclear oxovanadium(IV) complexes with tetradentate Schiff bases as ligands," Spectrochimica Acta A, vol. 58, no. 12, pp. 26512657, 2002.

[42] R. Kannappan, R. Mahalakshmy, T. M. Rajendiran, R. Venkatesan, and P. Sambasiva Rao, "Magnetic, catalytic, EPR and electrochemical studies on binuclear copper(II) complexes derived from 3,4-disubstituted phenol," Proceedings of the Indian Academy of Sciences, vol. 115, no. 1, pp. 1-14, 2003.

[43] D. N. Satyanarayana, Electronic Absorption Spectroscopy and Related Techniques, Universities Press, India, 2001.

[44] Y. Jadegoud, O. B. Ijare, B. S. Somashekar, G. A. N. Gowda, and B. H. M. Mruthyunjayaswamy, "Synthesis, characterization and antimicrobial activity of homodinuclear complexes derived from 2,6-bis[3'-methyl- $2^{\prime}$ - carboxamidyliminomethyl $\left(6^{\prime}, 7^{\prime}\right)$ benzindole]-4-methylphenol, an end-off compartmental ligand," Journal of Coordination Chemistry, vol. 61, no. 4, pp. 508-527, 2008.

[45] A. A. El-Bindary and A. Z. El-Sonbati, "Synthesis and properties of complexes of copper(II), nickel(II), cobalt(II) and uranyl ions with 3-(p-tolylsulphonamido)rhodanine," Polish Journal of Chemistry, vol. 74, no. 5, pp. 615-620, 2000.

[46] F. A. Cotton and G. Wilkinson, Advanced Inorganic Chemistry, John Wiley \& Sons, New York, NY, USA, 3rd edition, 1972. 
[47] N. H. Pilkington and R. Robson, "Corrigenda-complexes of binucleating ligands. III. Novel complexes of a macrocyclic binucleating ligand," Australian Journal of Chemistry, vol. 23, pp. 2225-2236, 1970.

[48] B. J. Hathaway and D. E. Billing, "The electronic properties and stereochemistry of mono-nuclear complexes of the copper(II) ion," Coordination Chemistry Reviews, vol. 5, no. 2, pp. 143-207, 1970.

[49] V. P. Singh, P. Singh, and A. K. Singh, "Synthesis, structural and corrosion inhibition studies on cobalt(II), nickel(II), copper(II) and zinc(II) complexes with 2-acetylthiophene benzoylhydrazone," Inorganica Chimica Acta, vol. 379, no. 1, pp. 56-63, 2011.

[50] A. K. Sharma and S. Chandra, "Complexation of nitrogen and sulphur donor Schiff's base ligand to $\mathrm{Cr}(\mathrm{III})$ and $\mathrm{Ni}(\mathrm{II})$ metal ions: synthesis, spectroscopic and antipathogenic studies," Spectrochimica Acta A, vol. 78, no. 1, pp. 337-342, 2011.

[51] Z. H. Chohan, M. Arif, M. A. Akhtar, and C. T. Supuran, "Metalbased antibacterial and antifungal agents: synthesis, characterization, and in vitro biological evaluation of $\mathrm{Co}(\mathrm{II}), \mathrm{Cu}(\mathrm{II})$, $\mathrm{Ni}(\mathrm{II})$, and $\mathrm{Zn}$ (II) complexes with amino acid-derived compounds," Bioinorganic Chemistry and Applications, vol. 2006, Article ID 83131, 13 pages, 2006.

[52] Z. H. A. El-Wahab, M. M. Mashaly, A. A. Salman, B. A. ElShetary, and A. A. Faheim, "Co(II), Ce(III) and UO2(VI) bissalicylatothiosemicarbazide complexes: binary and ternary complexes, thermal studies and antimicrobial activity," Spectrochimica Acta A, vol. 60, no. 12, pp. 2861-2873, 2004.

[53] K. R. K. Reddy, P. Suneetha, C. S. Karigar, N. H. Manjunath, and K. N. Mahendra, "Cobalt(II), Ni(II), Cu(II), Zn(II), CD(II), $\mathrm{Hg}(\mathrm{II}), \mathrm{U} 02$ (VI) and th(IV) complexes from ONNN Schiff base ligand," Journal of the Chilean Chemical Society, vol. 53, no. 4, pp. 1653-1657, 2008.

[54] A. Sitlani, E. C. Long, A. M. Pyle, and J. K. Barton, "DNA photocleavage by phenanthrenequinone diimine complexes of rhodium(III): shape-selective recognition and reaction," Journal of the American Chemical Society, vol. 114, no. 7, pp. 23032312, 1992. 

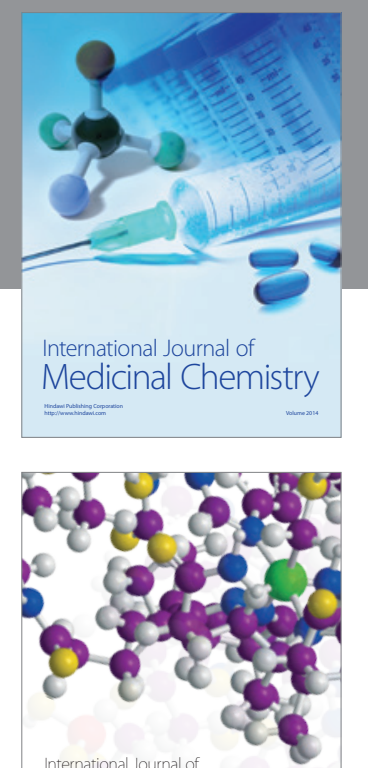

\section{Carbohydrate} Chemistry

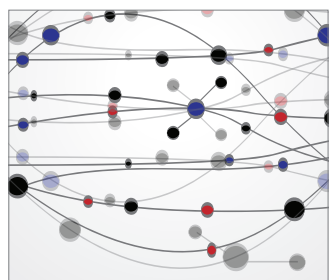

The Scientific World Journal
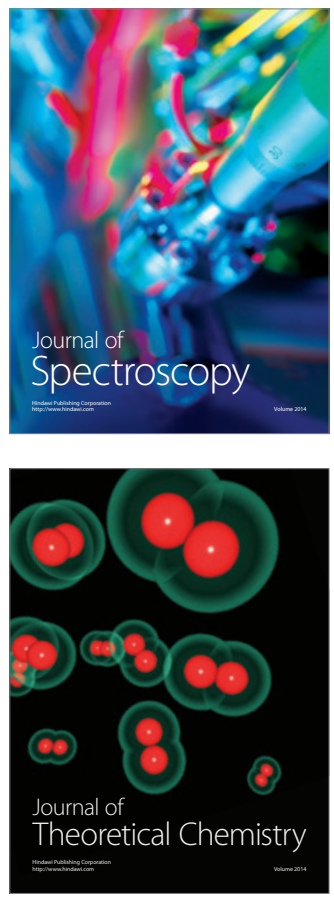
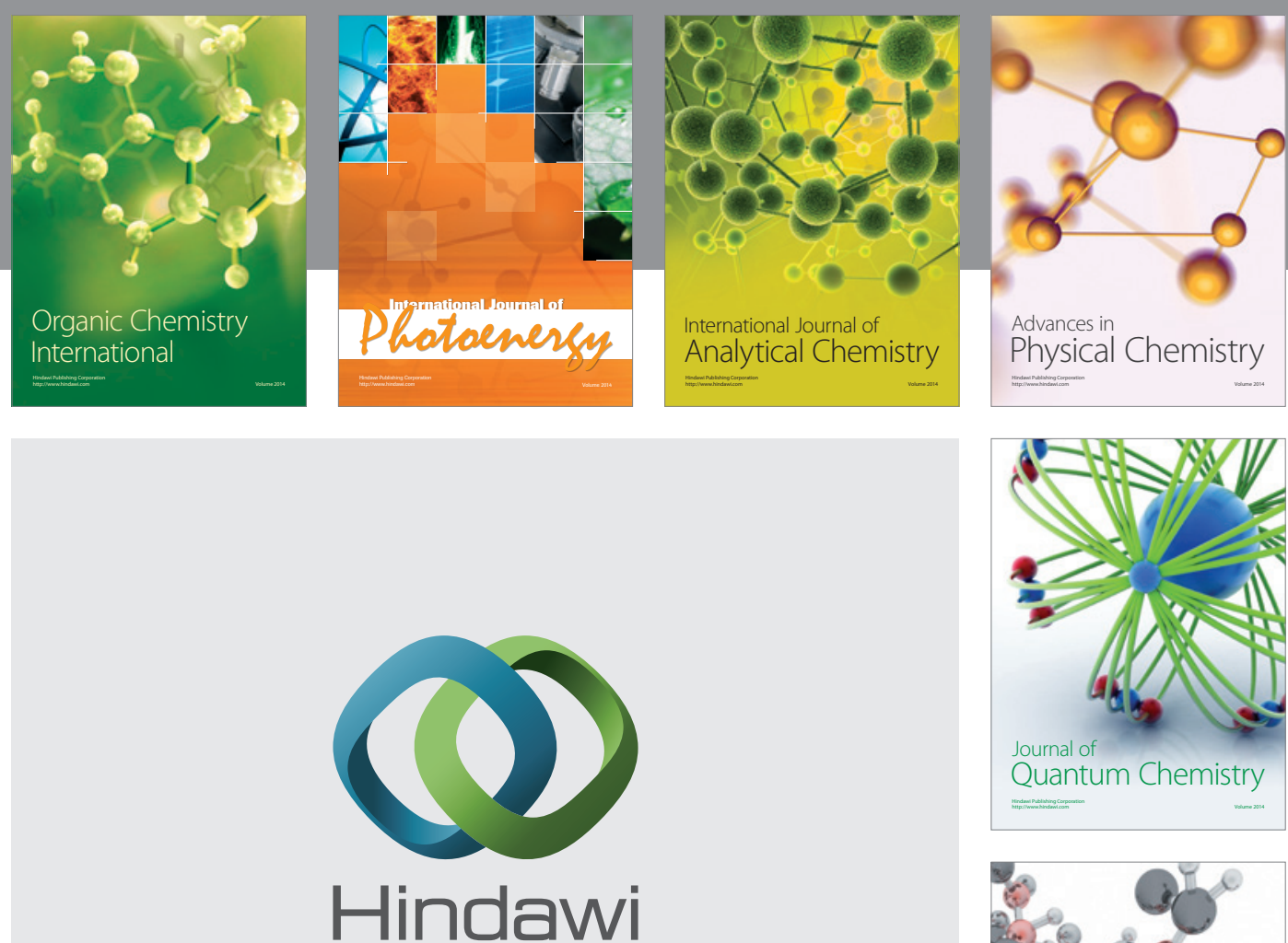

Submit your manuscripts at

http://www.hindawi.com

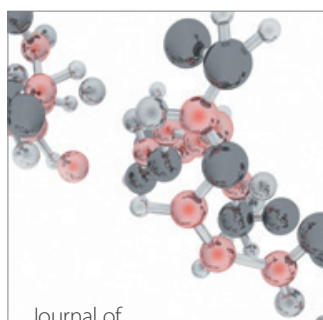

Analytical Methods

in Chemistry

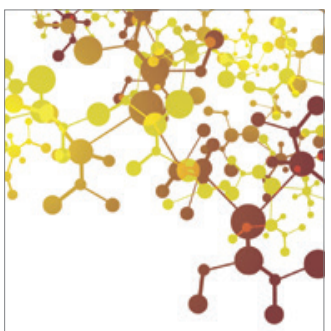

Journal of

Applied Chemistry

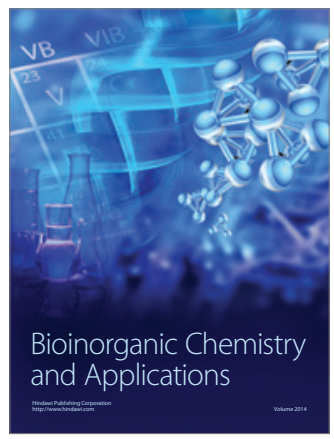

Inorganic Chemistry
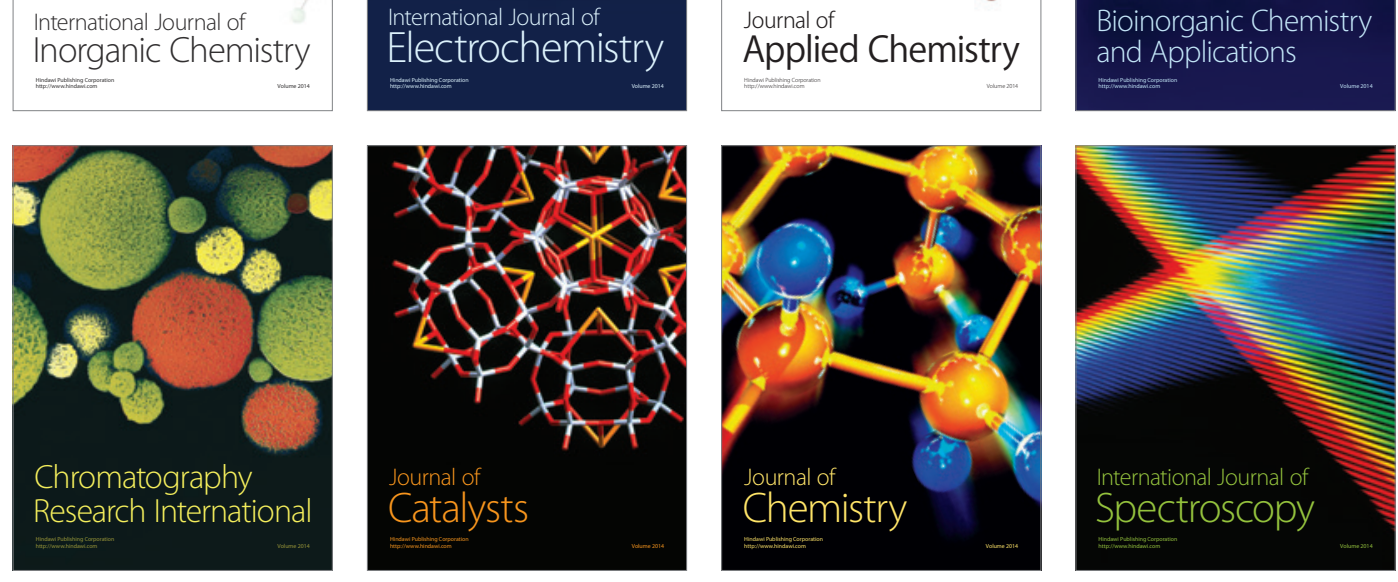